\title{
Silicon cycle in the NW Mediterranean Sea: seasonal study of a coastal oligotrophic site
}

\section{Cycle de la silice en Méditerranée nord-occidentale : étude saisonnière d'un site côtier oligotrophe}

\author{
Karine Leblanc *, Bernard Quéguiner, Nicole Garcia, Peggy Rimmelin, Patrick Raimbault \\ Laboratoire d'Océanographie et de Biogéochimie, UMR 6535-CNRS, Campus de Luminy Case 901, 13288 Marseille cedex 9, France
}

Received 22 January 2002; received in revised form 21 May 2002; accepted 24 May 2002

\begin{abstract}
A study of the biogeochemical cycle of silicon has been conducted in the Gulf of Lion (NW Mediterranean) from September 1999 to September 2000. Most of the year the study site was under the influence of the NW Mediterranean Current, characterized by oligotrophic conditions. A seasonal pattern of silicon stocks was found, showing an inverse annual distribution of biogenic silica and lithogenic silica. Biogenic silica integrated stocks were higher during spring and summer (21.5 and $\left.19.3 \mathrm{mmol} \mathrm{m}^{-2}\right)$ due to siliceous phytoplankton Si uptake and build-up of biomass. By contrast lithogenic silica integrated stocks were highest during the fall and winter $\left(61.8\right.$ and $\left.45.0 \mathrm{mmol} \mathrm{m}^{-2}\right)$, which may be explained by a higher degree of turbulence of the water column, inducing sediment resuspension. Phytoplankton counts showed that the relative contribution of diatoms to microphytoplankton at the chlorophyll $a$ maximum averaged $51 \%$ during the study period. Si uptake rates, measured in situ from March to September 2000, were low $\left(\Sigma \rho \mathrm{Si}=0.14-1.4 \mathrm{mmol} \mathrm{Si} \mathrm{m}{ }^{-2} \mathrm{~d}^{-1}\right)$ throughout the study period. Potential $\mathrm{Si}$ limitation of siliceous phytoplankton in the course of spring bloom development was evidenced both by Si enrichment kinetics, yielding relatively high $K_{\mathrm{S}}$ values (3.46 and $4.97 \mu \mathrm{M}$ ), and by nutrient distributions, exhibiting Si exhaustion over the entire water column by mid-April.

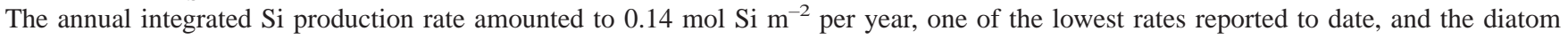
contribution to annual carbon primary production was estimated to range between 24 and $36 \%$. The silicon cycle at the NW Mediterranean site was similar to that observed in other oligotrophic open-ocean systems in terms of stocks, annual Si production rates, and the relative contribution of diatoms to phytoplanktonic primary production.
\end{abstract}

(C) 2003 Éditions scientifiques et médicales Elsevier SAS and Ifremer/CNRS/IRD. All rights reserved.

\section{Résumé}

Une étude saisonnière du cycle du silicium a été réalisée dans le golfe du Lion (Méditerranée nord-Occidentale) de septembre 1999 à septembre 2000. Le site d'étude est placé sous l'influence du Courant Nord méditerranéen, dont les eaux sont oligotrophes. La variation saisonnière des stocks de Si montre une distribution annuelle inverse de la silice biogénique et de la silice lithogénique. Les stocks intégrés de la silici biogénique sont plus élevés au printemps et en été $\left(21,5\right.$ et 19,3 $\mathrm{mmol} \mathrm{m}^{-2}$ ) en raison de l'absorption de Si par le phytoplancton et de l'accumulation de biomasse dans la colonne d'eau. En revanche, les stocks intégrés de la silice lithogénique sont plus élevés en automne et en hiver (61,8 et 45,0 $\mathrm{mmol} \mathrm{m}^{-2}$ ), ce qui peut s'expliquer par l'augmentation de la turbulence dans la colonne d'eau, favorisant la remise en suspension du sédiment. Les diatomées représentent en moyenne sur l'année $51 \%$ du microphytoplancton au maximum de Chl $a$. La

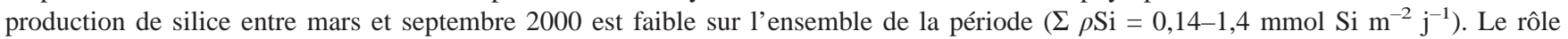
potentiellement limitant du silicium au cours du développement printanier est démontré par les cinétiques d'enrichissement, qui aboutissent à des valeurs de $K_{\mathrm{S}}$ relativement élevées $(3,46$ et 4,97 $\mu \mathrm{M})$ et par la distribution de l'acide orthosilicique, qui est épuisé sur l'ensemble de la

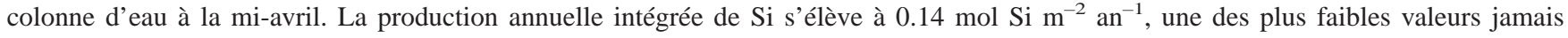
documentée, et la contribution des diatomées à la production primaire annuelle est estimée à 24-36\%. Le cycle du silicium dans le Courant Nord méditerranéen présente des caractéristiques communes avec d'autres systèmes oligotrophes de l'océan ouvert, en terme de stocks, de production annuelle de $\mathrm{Si}$ et de contribution des diatomées à la production primaire phytoplanctonique.

(C) 2003 Éditions scientifiques et médicales Elsevier SAS and Ifremer/CNRS/IRD. All rights reserved.

* Corresponding author. Fax: +33-4-91-82-19-91.

E-mail address: karine.leblanc@com.univ-mrs.fr (K. Leblanc). 
Keywords: NW Mediterranean; Biogenic silica; Phytoplanktonic community; Limiting nutrient; Seasonal cycle

Mots clés : Méditerranée nord-occidentale ; Cycle de la silice ; Communauté phytoplanctonique ; Nutriment limitant ; Cycle saisonnier

\section{Introduction}

Continental margins are known to play a major role in global biogeochemical cycles. Although they occupy only $8 \%$ of the ocean's surface, they contribute to between 18 and $33 \%$ of global oceanic primary production (Wollast, 1991). Up to $75 \%$ of the carbon burial occurs in margins (Liu et al., 2000). At the confluence of marine, terrestrial and atmospheric influences, coastal areas often exhibit higher fertility by comparison to open ocean zones, mainly due to river nutrient discharges and human activities. Coastal margins, due to their shallow depth, are the site of enhanced $\mathrm{CO}_{2}$ sequestration in sediments through the biological pump (Berger et al., 1989). As a consequence, numerous studies on primary production and export of organic matter have been conducted in these areas, but most often focused on $\mathrm{C}, \mathrm{N}$ or $\mathrm{P}$ cycling and annual budgets. Silicon, however, is a major component of marine biogenic matter, since its uptake under the dissolved form is essential to diatom growth, a siliceous phytoplanktonic group, which often dominates pelagic assemblages. The contribution of diatoms to global primary productivity varies between 25 and $30 \%$ in open ocean oligotrophic areas to up to $75 \%$ in eutrophic coastal areas (Nelson et al., 1995), but the importance of $\mathrm{Si}$ in driving new production has long been ignored (Dugdale and Minas, 1995). The dominance of diatoms in a phytoplanktonic assemblage is of major importance for the biological pump, since they export $\mathrm{C}$ more efficiently than non-siliceous (flagellates) species. Large enclosure experiments demonstrated that moderate $\mathrm{Si}(\mathrm{OH})_{4}$ addition resulted in a two-fold increase of C primary production (Egge and Jacobsen, 1997) and in an increased vertical C export by $18 \%$ (Wassmann et al., 1996).

In the last decade, several studies have observed an increasing dystrophy in coastal waters $(\mathrm{CW})$ submitted to the influence of riverine discharges. A consequent decrease in the $\mathrm{Si}: \mathrm{N}$ ratio appears to be a general trend in various coastal areas. This is the case in the Adriatic Sea (Po), the North Sea (Rhine/Elbe), the Gulf of Mexico (Mississippi) (Smayda, 1990; Jickells, 1998) and the Bay of Brest (Aulne/Elorn) (Del Amo et al., 1997; Le Pape et al., 1996). As hypothesized by Officer and Ryther (1980) and Smayda (1990), a decrease in the Si:N ratio would lead to a predominance of nonsiliceous (flagellates) and sometimes toxic species over diatoms, resulting in undesirable eutrophication effects such as anoxic conditions, fish and shellfish mortality, and harmful algal blooms. Several authors have even evoked Si addition to nutrient discharges as a potential solution to eutrophication problems (Officer and Ryther, 1980; Wassmann et al., 1996). In the Gulf of Mexico, however, the effect of nutrient dystrophy rather led to a shift within the diatom community, favoring species with high affinity constants for $\mathrm{Si}(\mathrm{OH})_{4}$, rather than a shift towards non-siliceous species (Nelson and Dortch, 1996).

Few studies concerning the silicon cycle on continental margins are available (Shipe and Brzezinski, 2001; Del Amo et al., 1997; Nelson and Dortch, 1996; Ragueneau and Tréguer, 1994; Officer and Ryther, 1980; Nelson and Goering, 1978) and even fewer address the Mediterranean Sea. In the Northwestern Mediterranean, biogenic silica (BSi) profiles were derived by Copin-Montégut (1988), Price et al. (1999) and opal (BSi) rain rates have been measured in sediment traps in the Adriatic and in the Gulf of Lions (GL) (Miserocchi et al., 1999; Monaco et al., 1990). Orthosilicic acid $\left(\mathrm{Si}(\mathrm{OH})_{4}\right)$ concentrations are rarely systematically measured in parallel with other nutrients. Some profiles were presented in Coste and Minas (1977), Béthoux et al. (1998), Conan (1996) and Denis (1999) for the Northwestern Mediterranean and for the GL. As for direct silicon uptake rate measurements in the Mediterranean Sea, none have been published yet to our knowledge.

Results presented in this paper aim at providing some additional data concerning the silicon cycle in CWs, with measurements made throughout an annual cycle at a study site in the Northwestern Mediterranean. The GL is a complex hydrological area, due to the inputs of fresh water from the Rhone river, to the entrance of Modified Atlantic Waters (MAW) originating from the Northern Mediterranean Current (NMC), to frequent episodic wind stress from the North West and to intense convection events during winter (Millot, 1990). This article addresses the seasonal variations of the $\mathrm{Si}$ cycle in the GL and estimates annual Si standing stocks and fluxes while integrating shifts in phytoplanktonic communities. One of the objectives of this paper is to determine to what extent nutrients, in particular $\mathrm{Si}$, exert a control over primary production and over the floristic composition of the phytoplanktonic community. The contribution of diatoms to primary production is assessed by in situ $\mathrm{C}$ and $\mathrm{Si}$ uptake measurements. Finally, we try to characterize the silicon cycle by the season and by the main hydrological features encountered in this area.

\section{Material and methods}

\subsection{Sampling strategy}

This study was part of the Site d'Observation FIxe (SOFI) program, a contribution to the French Programme National d'Océanographie Côtière (PNOC) which aimed at establishing $\mathrm{C}$ and $\mathrm{N}$ annual budgets on continental margins. The 
SOFI program focused more particularly on the temporal variability of primary production, export and burial of organic matter at a coastal site. The campaigns started in 1998, but the analyses concerning the silicon cycle were carried out only from September 1999 to September 2000 on board the R/Vs Tethys and Georges Petit (INSU/CNRS). The SOFI site was located in the GL $\left(5^{\circ} 07^{\prime} 600 \mathrm{E} 43^{\circ} 04^{\prime} 000 \mathrm{~N}\right)$ at $162 \mathrm{~m}$ depth on the edge of the continental slope 20 miles off Marseille Fig. 1). This location allowed a minimum transit time from Marseille and was considered to be only rarely under the influence of the Rhone river. Campaigns occurred generally once a month except in April where campaigns occurred on a weekly basis in order to better characterize the spring bloom Table 1. December, January and August months were not sampled due to ship immobilization.

\subsection{Dissolved and particulate matter analysis}

Water was collected at 12 discrete depths: 5, 20, 30, 40, $50,60,70,80,90,100,120$ and $150 \mathrm{~m}$ with 121 Niskin
Table 1

The names and dates of the missions at SOFI are listed in this table, a square indicates when $\mathrm{Si}$ and $\mathrm{C}$ uptake rate measurements were carried out

\begin{tabular}{llll}
\hline Missions & Dates & $\rho \mathrm{Si}$ & $\rho \mathrm{C}$ \\
\hline SOFI 6-99 & $10 / 09 / 99$ & & \\
SOFI 7-99 & $04 / 11 / 99$ & & \\
SOFI 8-99 & $25 / 11 / 99$ & & $\mathbf{\square}$ \\
SOFI 1-00 & $05 / 02 / 00$ & & $\mathbf{\square}$ \\
SOFI 2-00 & $30 / 03 / 00$ & $\mathbf{\square}$ & \\
SOFI 3-00 & $08 / 04 / 00$ & & \\
SOFI 4-00 & $14 / 04 / 00$ & $\mathbf{\square}$ \\
SOFI 5-00 & $30 / 04 / 00$ & $\mathbf{\square}$ & $\mathbf{\square}$ \\
SOFI 6-00 & $28 / 05 / 00$ & $\mathbf{\square}$ \\
SOFI 7-00 & $12 / 06 / 00$ & $\mathbf{\square}$ \\
SOFI 8-00 & $17 / 07 / 00$ & $\mathbf{\square}$ \\
SOFI 9-00 & $14 / 09 / 00$ & $\mathbf{\square}$
\end{tabular}

bottles mounted on a Seabird CTDO rosette sampler (model SBE 911+). Water samples were filtered and fixed on board and later analyzed at the laboratory for dissolved and particulate matter ( $\mathrm{Si}, \mathrm{C}, \mathrm{N}, \mathrm{P})$. Particulate $\mathrm{C}, \mathrm{N}$ and $\mathrm{P}$ were analyzed
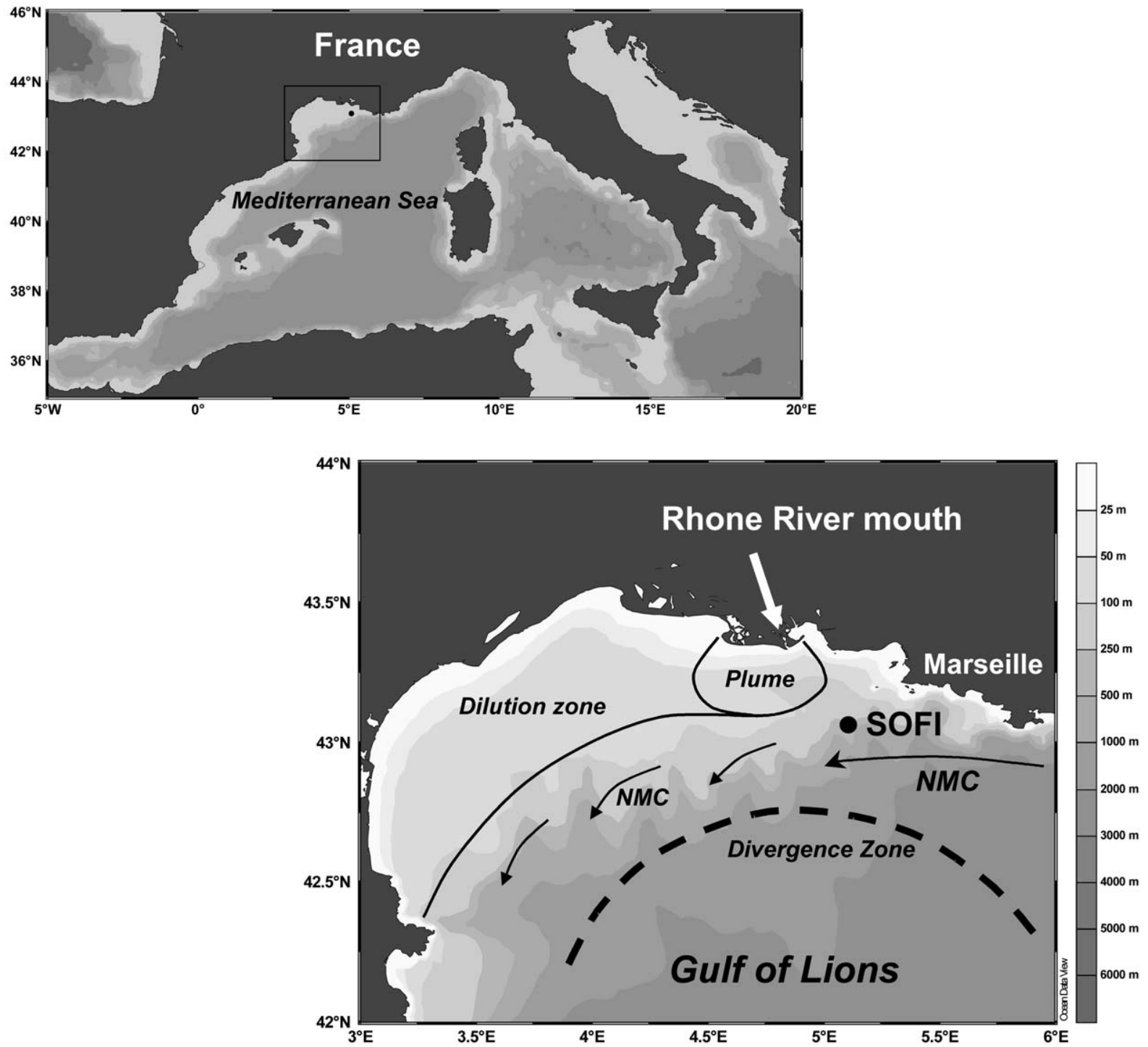

Fig. 1. Study site (SOFI) location. NMC: North Mediterranean Current. Modified from Diaz (2000). Mapping freeware: Ocean Data View (Schlitzer, 2002). 
using the wet oxidation method as described in Raimbault et al. (1999).

Orthosilicic acid $\left(\mathrm{Si}(\mathrm{OH})_{4}\right)$ concentrations were analyzed using the colorimetric method of Strickland and Parsons (1972), modified by Brzezinski and Nelson (1986) on a CECIL (CE 1011) spectrofluorometer, with a detection limit of $50 \mathrm{nM}$. $\left[\mathrm{NH}_{4}\right]$ was measured manually using the colorimetric method of Koroleff (1969) with a detection limit of $30 \mathrm{nM}$. $\left[\mathrm{NO}_{3}\right],\left[\mathrm{NO}_{2}\right]$ and $\left[\mathrm{PO}_{4}\right]$ were measured by standard automated colorimetric methods (Tréguer and Le Corre, 1975) on a Technicon autoanalyzer with a detection limit of $20 \mathrm{nM}$ for $\mathrm{PO}_{4}$ and $50 \mathrm{nM}$ for dissolved inorganic nitrogen $\left(\mathrm{DIN}=\left[\mathrm{NH}_{4}\right]+\left[\mathrm{NO}_{3}\right]+\left[\mathrm{NO}_{2}\right]\right)$.

For particulate $\mathrm{Si}, 11$ seawater was filtered on board on $0.6 \mu \mathrm{m}$ polycarbonate membranes ( $47 \mathrm{~mm}$, Nucleopore). BSi was measured using the hot $\mathrm{NaOH}$ digestion technique for 45 min and lithogenic silica (LSi) was subsequently digested with HF for 48 h, according to Nelson et al. (1989).

Chlorophyll $a(\mathrm{Chl} a)$ was determined after filtration on board using $125 \mathrm{ml}$ of seawater on pre-combusted GF/F filters (25 mm, Whatman). Extraction was carried out in methanol for $30 \mathrm{~min}$ and fluorescence of the extract was measured by fluorometry (fluorometer Turner Design, model 10.005R) (Raimbault et al., 1988).

\subsection{Si uptake measurements $(\rho S i)$}

Dawn-to-dawn in situ uptake experiments were realized using an immersed production line, at six incubation depths corresponding respectively to $50(5 \mathrm{~m}), 25(20 \mathrm{~m}), 15$, (30 $\mathrm{m}), 8(40 \mathrm{~m}), 4(50 \mathrm{~m})$ and $1 \%(70 \mathrm{~m})$ of incoming surface light.

Seawater $(275 \mathrm{ml})$ sampled before dawn, were spiked with $0.022 \mu \mathrm{Ci}(800 \mathrm{~Bq})$ of the radioactive isotope silicon-32 $\left({ }^{32} \mathrm{Si}\right)$. The specific activity of the ${ }^{32} \mathrm{Si}$ solution was $15.5 \mathrm{kBq}$ $\mu \mathrm{g} \mathrm{Si}{ }^{-1}$. For three samples out of $42, \mathrm{Si}$ addition increased initial $\left[\mathrm{Si}(\mathrm{OH})_{4}\right]$ by 1,4 and $18 \%$, respectively. For all other samples Si addition did not exceed $1 \%$ of the initial concentration. After incubation, samples were filtered on polycarbonate Nucleopore membrane $(0.6 \mu \mathrm{m}, 47 \mathrm{~mm})$. Filters were rinsed with filtered $(0.2 \mu \mathrm{m})$ seawater, and placed in scintillation vials. The ${ }^{32} \mathrm{Si}$ uptake was measured in a Packard 1600-TR scintillation counter by Cerenkov effect, following the method described by Tréguer et al. (1991) and Leynaert (1993). Precision of the method averages 10\%. Si specific uptake rates VSi (in $\mathrm{d}^{-1}$ ) have been derived from $\mathrm{BSi}$ and $\rho \mathrm{Si}$ measurements using the following equation:

$$
V S i=\frac{\rho S i}{B S i}
$$

BSi doubling time $k$ (in doublings $\mathrm{d}^{-1}$ ) is calculated as follows, assuming logarithmic growth:

$$
k=\frac{\ln \frac{B S i+\Delta B S i}{B S i}}{\ln (2)}
$$

where $\triangle \mathrm{BSi}$ is the BSi increase during $1 \mathrm{~d}$ and has the same value as $\rho \mathrm{Si}$ with nmol $1^{-1}$ units.

\subsection{Si kinetics $\left(K_{S}\right.$ and $\left.V_{\max }\right)$}

Due to a limited ${ }^{32} \mathrm{Si}$ solution stock, only two kinetic uptake experiments were made on the last two cruises, SOFI 8-00 and SOFI 9-00. Samples used were issued from the same Niskin bottles as those used for in situ incubation and the depths chosen corresponded to the Chl $a$ maximum. Six samples from each depth received non-radioactive $\mathrm{Si}\left(\mathrm{OH}_{4}\right)$ additions so that concentrations increased respectively by 0 , $0.5,1,1.5,2,5$ and $10 \mu \mathrm{M}$. Bottles were incubated on board in a deck incubator for $8 \mathrm{~h}$ using neutral nickel screens. Samples were, thereafter, treated as described for in situ samples. Kinetic parameters $V_{\max }$ and $K_{\mathrm{S}}$ were calculated by fitting the data to a Michaelis-Menten curve using the procedure described by Wilkinson (1961).

\subsection{Phytoplankton counting}

Between one and three depths were chosen during each cruise, according to the position of the fluorescence maximum. For each depth two samples were collected and treated with two different fixing reagents: buffered formaldehyde and acidified Lugol which allowed, respectively, good coccolithophorid and diatom preservation. Formaldehyde fixation is qualitatively selective in that it distorts cell shape of naked flagellates (Sournia, 1978). Diatom and flagellates quantification was done using the Lugol samples, while coccolithophorids were quantified in the formaldehyde samples. Identification and counting of nano- and microplankton were made by direct observation using an inversed microscope according to Utermöhl (1931).

\section{Results}

\subsection{Hydrological environment}

The Gulf of Lions is a complex hydrological area where different water bodies interact and can be subdivided into several hydrological systems of variable fertility Fig. 1. Surface waters are primarily MAWs entering the GL under the influence of the NMC. The NMC flows from the east to the west along the continental slope, forming meanders from a few tens of $\mathrm{km}$ up to a few hundreds of $\mathrm{km}$ wide (Millot, 1999). The current is $20-50 \mathrm{~km}$ broad and $100-200 \mathrm{~m}$ thick according to the season. The NMC indeed exhibits marked seasonal variations: the current stream is narrower, closer to the continental slope and extends deeper in winter than in summer (Conan and Millot, 1995). The $\theta-S$ diagrams Fig. 2 . showed that the SOFI site was under the influence of the NMC most of the year with a predominance of MAW in surface waters characterized by salinity values ranging between 37.9 and 38.45 and relatively high temperatures (Conan, 1996). When the NMC lies at its southernmost position, or when strong northwesterly winds (Mistral) occur, the SOFI site may occasionally be under the influence of diluted $\mathrm{CWs}$ discharged from the Rhone river. $\mathrm{CW}$ flows to the west 
Table 2

Characteristics of the different water masses at the SOFI site. From Lacombe and Tchernia (1972) modified by Conan (1996)

\begin{tabular}{llll}
\hline & Temperature $\left({ }^{\circ} \mathrm{C}\right)$ & Salinity & $\begin{array}{l}\text { Potential density } \\
\text { anomaly }\end{array}$ \\
\hline MAW & {$[13.25-13.35]-$ max } & $37.90-38.45$ & $>27.00-29.00$ \\
CW & Variable-variable & Min-<37.80 & Min-<28.60 \\
WIW & Min-<13.10 & $38.00-38.25$ & $28.70-<29.00$ \\
\hline
\end{tabular}

under normal conditions spreading into the northwestern part of the GL (Conan, 1996). CW, easily identifiable by salinity values <37.8, were observed at the SOFI site in July 2000. This extension of CW followed a period of $12 \mathrm{~d}$ of Mistral (strong and sustained northwesterly wind) prior to the SOFI 8-00 mission, and was clearly visible from Seawifs and AVHRR images. Aperiodic and strong wind events are a frequent feature in the GL, inducing a high short-scale (few days) variability (Millot, 1990). In winter, intense cooling and mixing of the water column results in the formation of Winter Intermediate Water (WIW) (Millot, 1999) characterized by temperatures $<13.1{ }^{\circ} \mathrm{C}$ and ranging between 38.00 and 38.25 in salinity. This phenomenon was observed from February to April (Fig. 2). The characteristics of the different water masses are resumed in Table 2

The seasonal evolution of temperature and salinity at the SOFI site is depicted in Fig. 3 During our survey, the lowest temperature $\left(13{ }^{\circ} \mathrm{C}\right)$ occurred in late-spring (FebruaryMarch), while the highest temperatures $\left(23-24{ }^{\circ} \mathrm{C}\right)$ were observed in late-summer/early-fall (September 1999 and September 2000). Stratification of the water column was first observed in late-April and was sustained until September. The thermocline extended as deep as $75 \mathrm{~m}$ in the beginning of November 1999 due to stronger mixing of the water column,

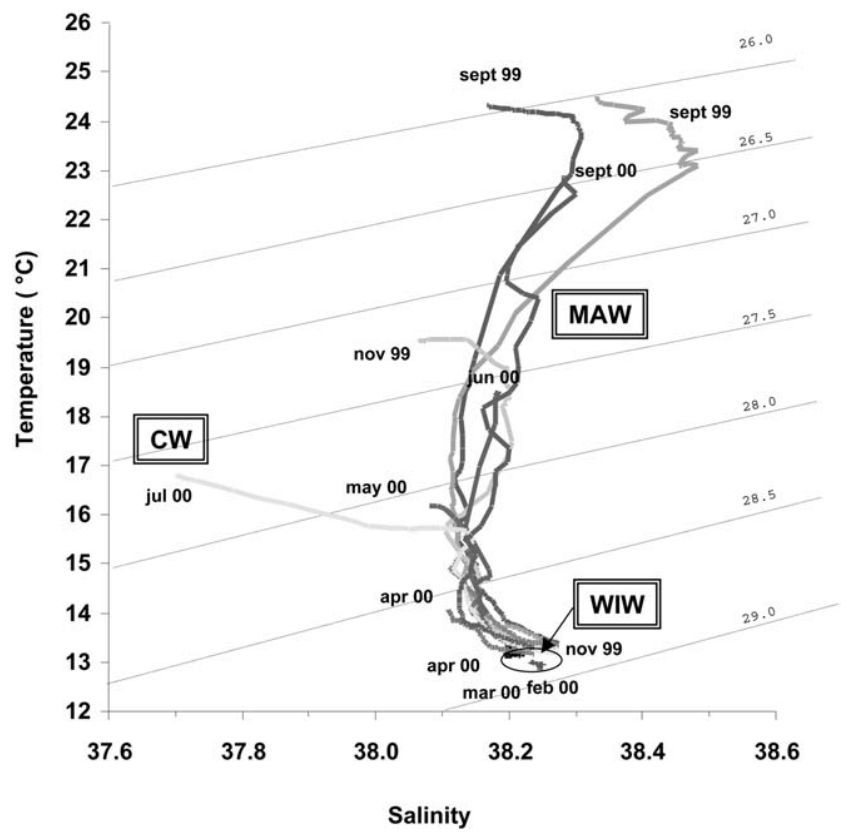

Fig. 2. Temperature-salinity diagram of the $0-150 \mathrm{~m}$ layer at SOFI. Dashed lines represent the isodensity lines. The water masses in presence were the MAW, the CW and the WIW. and began to be eroded at the end of November. Salinities throughout the study period were homogeneous (38.1-38.2) and representative of MAW, except in July where CWs reached SOFI, bringing the surface salinity down to 37.7.

\subsection{Nutrients}

All nutrients $\left(\mathrm{Si}(\mathrm{OH})_{4}, \mathrm{PO}_{4}\right.$, total DIN $\left(\mathrm{NO}_{3}+\mathrm{NO}_{2}+\right.$ $\left.\mathrm{NH}_{4}\right)$ ) showed the same seasonal trend Fig. 4. During winter (November-February), strong vertical mixing allowed the water column to be replenished with nutrients. The highest nutrients concentrations were observed at the end of November in bottom waters $\left(\left[\mathrm{Si}(\mathrm{OH})_{4}\right]=2.84 \mu \mathrm{M},\left[\mathrm{PO}_{4}\right]=\right.$ $\left.0.18 \mu \mathrm{M},\left[\mathrm{NO}_{3}\right]=5.2 \mu \mathrm{M}\right)$. Due to phytoplankton uptake, nutrients started to decrease in March and became severely depleted by the end of April when thermal stratification of the surface layer occurred. One of the most striking features was the severe Si depletion over the whole water column at the end of April $\left(\left[\mathrm{Si}(\mathrm{OH})_{4}\right]<0.12 \mu \mathrm{M}\right)$, which never occurred for the other nutrients. The depletion of DIN and $\mathrm{PO}_{4}$ paralleled Si depletion, but were confined to the euphotic layer $(0-70$ m). Si depletion concomitant to higher DIN concentrations has already been documented in the CWs of the Bay of Brest (Del Amo et al., 1997) and in the Dyfamed data base (long term study site off Villefranche, France). Oligotrophic conditions were sustained until late-summer/fall: DIN remained under the detection limit of $50 \mathrm{nM}$ in surface waters $(5-30 \mathrm{~m})$ from May to September while $\mathrm{PO}_{4}$ was very low $(<50 \mathrm{nM})$ in the first $60 \mathrm{~m}$ from April to September. Strong P, N and $\mathrm{Si}$ depletions, as deep as a $100 \mathrm{~m}$, were also observed at the beginning of the survey in early-November 1999; during that period $\mathrm{PO}_{4}$ remained under the detection limit from 5 to 100 m. In summer (July-August 2000), bottom waters showed an increase in nutrient concentrations from 90 to $150 \mathrm{~m}$ while surface values remained low.

\subsection{Particulate matter distribution}

The seasonal evolution of Chl $a$ is shown in Fig. 5a During fall and winter, minimum values ranging between 0.2 and $0.4 \mu \mathrm{g} \mathrm{l}^{-1}$ were observed over most of the water column. The deep distribution of Chl $a$ (up to $120 \mathrm{~m}$ ) in February was probably due to winter mixing, entraining phytoplankton cells out of the euphotic zone. The spring development started in the beginning of April, but Chl $a$ reached its highest concentration in May with $1.5 \mu \mathrm{g} \mathrm{l}^{-1}$ at $40 \mathrm{~m}$. A secondary bloom, associated with the presence of $\mathrm{CW}$ originating from the Rhone river Fig. 2 was observed in July; the highest values, measured between the surface and $50 \mathrm{~m}$, ranged between 1.0 and $1.2 \mu \mathrm{g} \mathrm{l^{-1 }}$.

BSi was measured using the hot $\mathrm{NaOH}$ digestion technique (Nelson et al., 1989). This method is well-suited for routine measurements of particulate silica in the open ocean, but corrections need to be made on data when using this technique in CWs (Ragueneau and Tréguer, 1994). Indeed, when water samples are enriched with $\mathrm{LSi}$, it has been shown that a fraction of the aluminosilicates present on the filter 

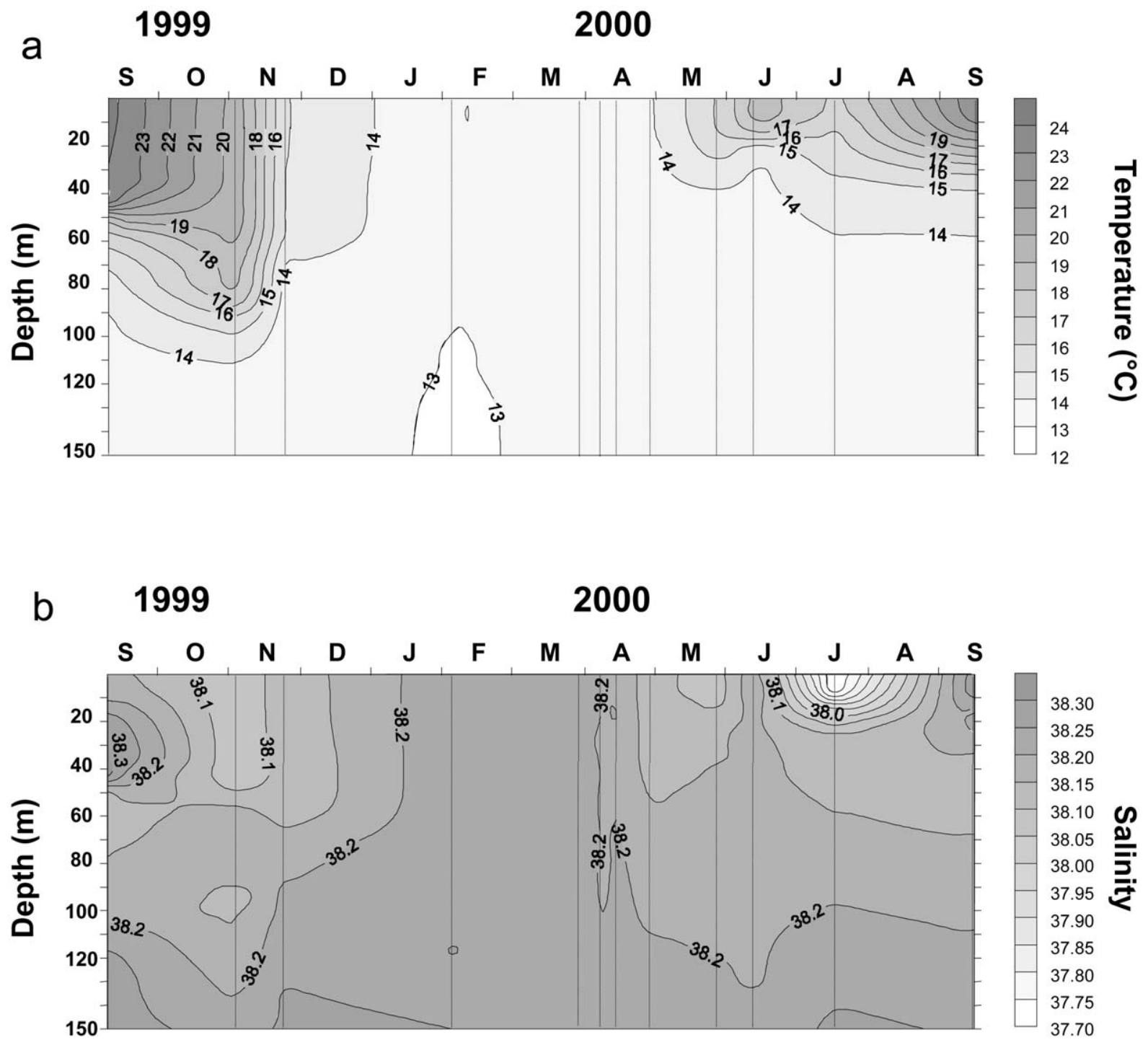

Fig. 3. Seasonal evolution of temperature and salinity at SOFI. Dashed lines represent each mission and CTD cast.

dissolves during the first $\mathrm{NaOH}$ extraction, resulting in an overestimation of $\mathrm{BSi}$ if data remain uncorrected. Ragueneau and Tréguer (1994) have shown that a fairly constant percentage of siliceous lithogenic material dissolves during the first alkaline extraction. This percentage is determined by using data collected in winter, when LSi concentrations are usually high and BSi are low, resulting in the highest degree of interference. Plotting LSi versus BSi (data used: SOFI 6-99, 7-99 and 8-99) yields a highly significant linear relationship $(r=0.78, v=30, \alpha=0.005)$ :

$$
\mathrm{BSi}_{\text {uncorrected }}=0.137 \times \mathrm{LSi}_{\text {uncorrected }}+0.0145
$$

From Eq. (3), the derived percentage of LSi interfering with $\mathrm{BSi}$ is $13.7 \%$, which is in very good agreement with the range of 14-16\% found for the Bay of Brest and the western English Channel by Ragueneau and Tréguer (1994). Thus, the subsequent corrections were applied:

$$
\mathrm{BSi}_{\text {corrected }}=\mathrm{BSi}_{\text {uncorrected }}-0.137 \times \mathrm{LSi}_{\text {uncorrected }}
$$

and

$$
\mathrm{LSi}_{\text {corrected }}=(\mathrm{BSi}+\mathrm{LSi})_{\text {uncorrected }}-\mathrm{BSi}_{\text {corrected }}
$$

BSi biomass slowly started accumulating in March with values exceeding $0.10 \mu \mathrm{mol} \mathrm{^{-1 }}$ but the spring bloom was delayed until May with high values restricted to the first $20 \mathrm{~m}$ Fig. 5b; concentrations reached the maximum value of 0.99 $\mu \mathrm{mol}{ }^{-1}$ at $5 \mathrm{~m}$. In June, the BSi declined to values $<0.25$ $\mu \mathrm{mol} \mathrm{l}^{-1}$ in the surface layer. A secondary peak was observed in July, during the Rhone event, where surface BSi reached up to $0.95 \mu \mathrm{mol} \mathrm{l}^{-1}$. No sinking of BSi was evidenced, since $\mathrm{BSi}$ remained confined in the first $80 \mathrm{~m}$ corresponding to the euphotic laver. A comparison with the seasonal evolution of Chl $a$ Fig. 5a shows that non-siliceous phytoplankton started developing very early in the season, with Chl $a$ values $>0.4 \mu \mathrm{g} \mathrm{l}^{-1}$ in November and February. During the productive period, the maximum biomass was observed at $40 \mathrm{~m}$, deeper than the BSi maximum.

LSi showed an inverse seasonal pattern as compared to BSi Fig. 5c. LSi was abundant in the water column during 

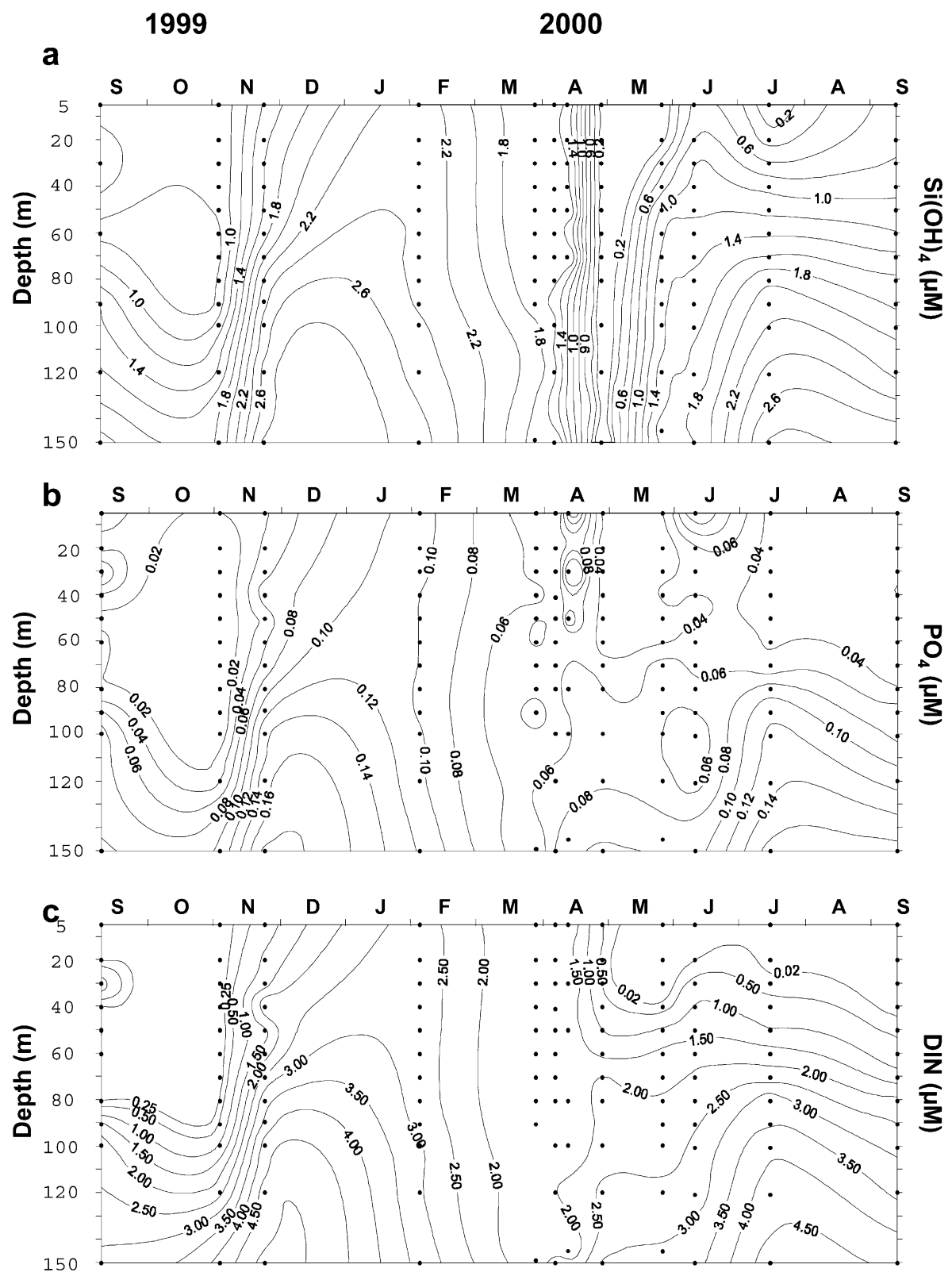

Fig. 4. Seasonal evolution of (a) orthosilicic acid $\left(\mathrm{Si}(\mathrm{OH})_{4}\right)$, (b) phosphates $\left(\mathrm{PO}_{4}\right)$ and (c) nitrates $\left(\mathrm{NO}_{3}\right)$ at SOFI. Units are in $\mu \mathrm{M}$.

fall and winter (September-April) while BSi accumulated in spring and summer (April-August). Very high concentrations $\left(2.13 \mu \mathrm{mol}^{-1}\right)$ were measured near the bottom in September 1999, probably due to the presence of a nepheloid layer flowing down along the continental slope. Concentrations in the surface layer $(0-70 \mathrm{~m})$ in September and November remained low $\left(<0.26 \mu \mathrm{mol}^{-1}\right)$ under conditions of stratification Fig. 3. As soon as the winter deep mixing occurred LSi values rose up to $0.40-0.60 \mu \mathrm{mol} \mathrm{l^{-1 }}$. LSi then declined $\left(<0.1 \mu \mathrm{mol} \mathrm{l}^{-1}\right)$ during spring and summer along with water warming and stratification. A slight increase was observed in July, corresponding to the input of fresher waters from the Rhone river, which were enriched with suspended lithogenic material.

\subsection{Si uptake and kinetic parameters}

In situ Si uptake rates $(\rho \mathrm{Si})$ were extremely low throughout the study (Fig. 6). Two peaks were measured in May during the spring bloom (26 nmol $\left.\mathrm{l}^{-1} \mathrm{~d}^{-1}\right)$ and in July (46 nmol $\mathrm{l}^{-1} \mathrm{~d}^{-1}$ ) during the Rhone river event. Maximum uptake rates were found at $30 \mathrm{~m}$ in May and July, below the $\mathrm{BSi}$ maximum, but corresponded to the $\mathrm{Chl} a$ maximum Fig. 5a b). A secondary maximum was also found at $5 \mathrm{~m}$ $\left(44 \mathrm{nmol} \mathrm{l}^{-1} \mathrm{~d}^{-1}\right)$ in July, coinciding with high BSi surface concentrations.

Specific Si uptake rates (VSi) Fig. 77 were highest in March and April, ranging between 0.11 and $0.13 \mathrm{~d}^{-1}$ at the surface corresponding to $\mathrm{BSi}$ doubling rates ranging between 

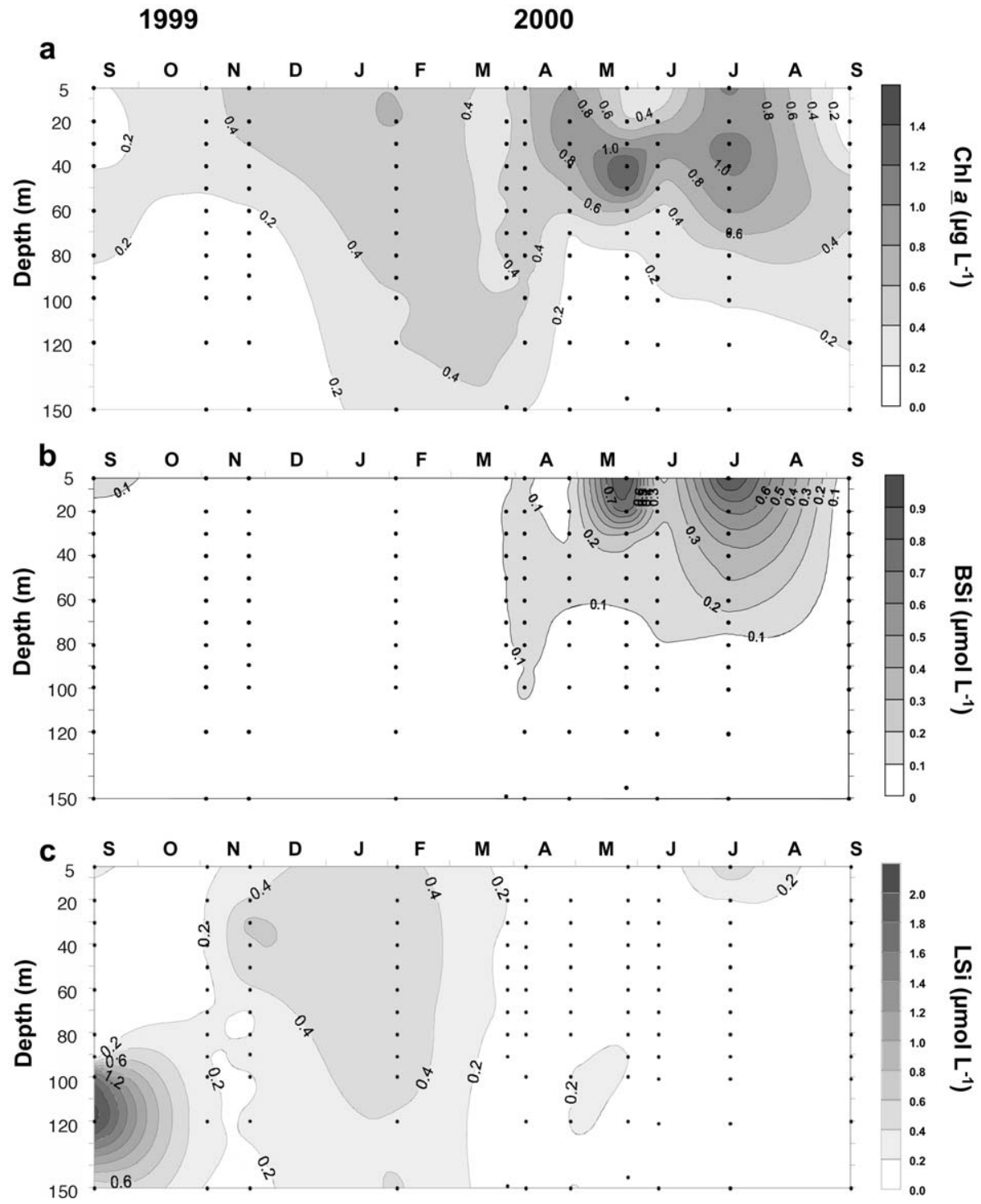

Fig. 5. Seasonal evolution of (a) Chl $a$ in $\mu g 1^{-1}$, (b) BSi in $\mu$ mol $1^{-1}$ and (c) LSi in $\mu$ mol $1^{-1}$ at SOFI.

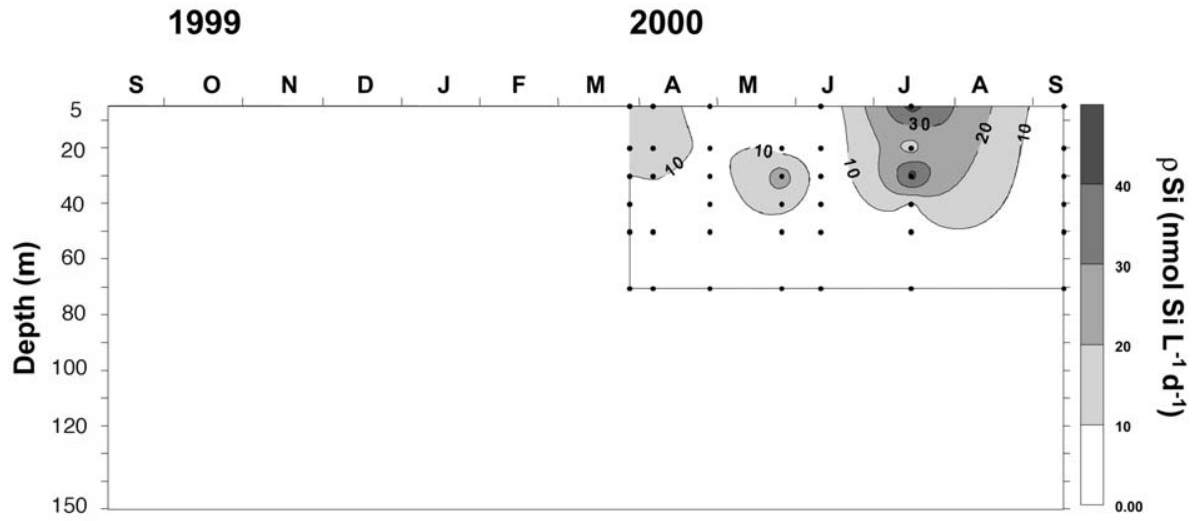

Fig. 6. Si uptake rates $(\rho \mathrm{Si})$ in $\mathrm{nmol} 1^{-1} \mathrm{~d}^{-1}$ at SOFI from March to September 2000 in the euphotic layer $(0-70 \mathrm{~m})$. 


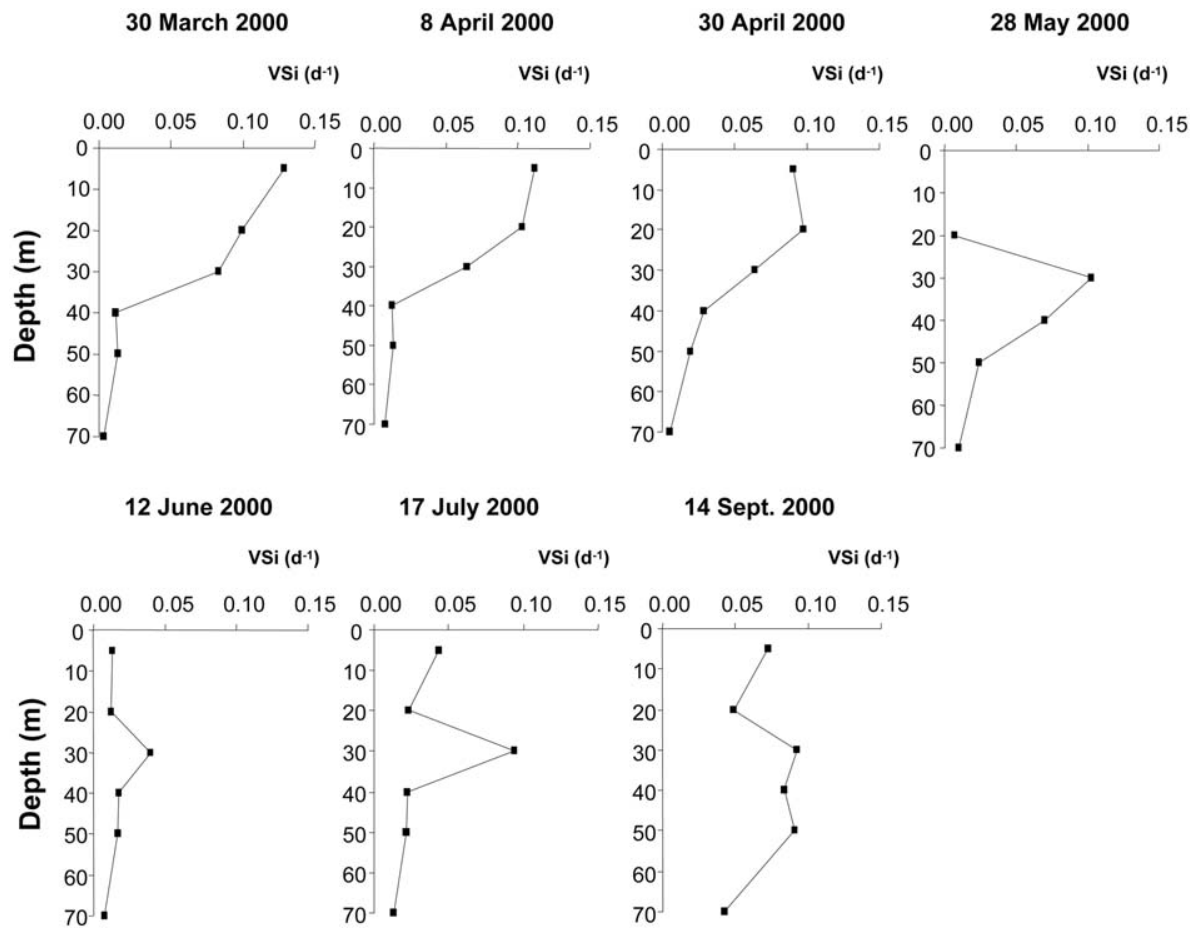

Fig. 7. Specific Si uptake rates profiles (VSi) in $\mathrm{d}^{-1}$ at SOFI from March to September 2000 in the euphotic layer $(0-70 \mathrm{~m})$.

0.15 and 0.18 doubl. $\mathrm{d}^{-1}$. During this period, specific uptake rates were high at the surface and rapidly decreased until $40 \mathrm{~m}$. From May and later on, the VSi maximums were located more at depth, around $30 \mathrm{~m}$, following the deeper $\mathrm{Chl}$ $a$ extension, and values varied from 0.04 to $0.10 \mathrm{~d}^{-1}$. Mean BSi doubling time for surface values throughout the study was 0.11 doubl. $\mathrm{d}^{-1}(9.5 \mathrm{~d})$.

Kinetic parameters were measured in July and September, at 40 and $50 \mathrm{~m}$, respectively, at the $\mathrm{Chl} a$ maximum [Fig. 8. $V_{\max }$ was five times greater in September $\left(0.97 \mathrm{~d}^{-1}\right)$ than in July during the Rhone event $\left(0.19 \mathrm{~d}^{-1}\right)$. The $V_{\text {ambient }} / V_{\max }$ ratio gives an indication of the degree of limitation of in situ specific uptake rates: in July, VSi at ambient concentration was only $27 \%$ of $V_{\max }$ while in September, VSi had increased up to $32 \%$ of $V_{\max } . K_{\mathrm{S}}$, the half-saturation constants were high, $3.46 \mu \mathrm{M}$ in July and $4.97 \mu \mathrm{M}$ in September and in any case much higher than ambient $\mathrm{Si}(\mathrm{OH})_{4}$ concentrations which were 0.95 and $1.11 \mu \mathrm{M}$, respectively.

\subsection{Phytoplankton communities}

Microphytoplankton (>20 $\mu \mathrm{m}$ ) cell number Fig. 9a was low and stable throughout fall and winter (SeptemberMarch). Cell abundance started to increase in the beginning of April, with 23000 cells $1^{-1}$, but was again low by mid-

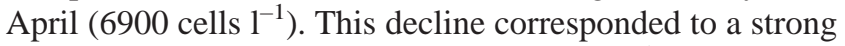
increase in ciliate number (19 000 cells $1^{-1}$ ) and to the presence at this period of swarms of pteropods (observed through zooplankton hauls and in sediment trap material), suggesting zooplankton control of phytoplankton abundance. During the spring bloom in May, when Chl $a$ was highest Fig. 9b, abundance rose up to 34000 cells $1^{-1}$. A strong increase in cell numbers occurred in July

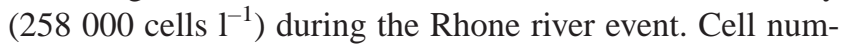
bers were one order of magnitude above spring values and were not matched by an equivalent increase in $\mathrm{Chl} a$. This exceptional situation was changed by the September sampling where cell abundances were within the range of more regular values (20 700 cells $\mathrm{I}^{-1}$ ). Nanophytoplankton $(<20 \mu \mathrm{m})$ abundance was high through out the year Fig. 9a

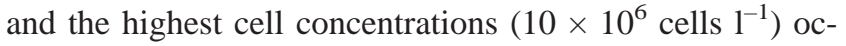
curred in late-April and May.

The dominant microphytoplankton species and their seasonal evolution are plotted in Fig. 10. Diatoms were the largest phytoplankton group in terms of mean annual relative contribution (51\%). The major diatom groups were, in order of importance, Leptocylindrus sp., Chaetoceros sp., PseudoNitzschia sp. and Rhizosolenia sp. During the Rhone event in July, the microphytoplankton community was almost entirely dominated by two diatom species (Leptocylindrus sp. = 130000 cells $1^{-1}$ and Pseudo-Nitzschia seriata = 92000 cells $^{-1}$ ) that were not observed at the SOFI site during the rest of the year. Dinoflagellates, essentially represented by Gymnodinium sp. and Gyrodinium sp. were present throughout the study period, with a mean annual relative abundance of 36\%. Silicoflagellates (Dictyocha sp.) and coccolithophorids (Syracosphaera sp., Rhabdosphaera sp.) were the least abundant groups.

Four different periods of major siliceous phytoplankton dominance were observed Fig. 11): at the end of November, in the beginning of April, and during the May and July 


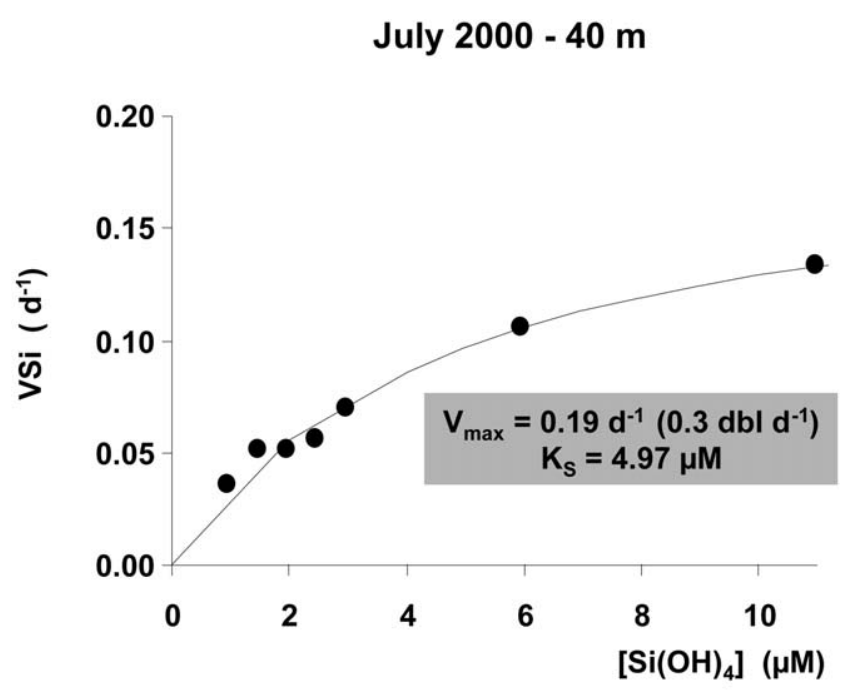

September $2000-50$ m

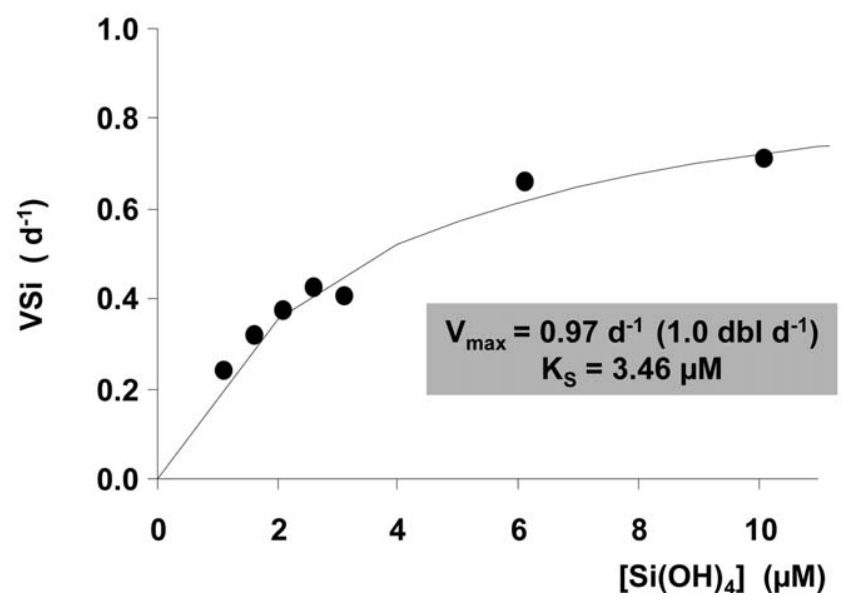

Fig. 8. Si enrichment kinetic experiments realized in deck incubators during $8 \mathrm{~h}$. The curves were adjusted to fit the Michaelis-Menten law using the procedure described by Wilkinson (1961). $V_{\max }$ is the potential maximum $\mathrm{Si}$ specific uptake rate (in $\mathrm{d}^{-1}$ ), and the equivalent potential doubling time is given in brackets (in doubl. $\mathrm{d}^{-1}$ ). The half-saturation constant, $K_{\mathrm{S}}$, is given in $\mu \mathrm{M}$.

blooms. The mean relative contribution of siliceous cells (diatoms + silicoflagellates) for the year study at the Chl $a$ maximum was $57 \%$.

\section{Discussion}

\subsection{Potential limiting nutrient}

The onset of the bloom at the SOFI site is driven by physical parameters such as increasing light intensity and thermal stratification (Diaz, 2000). However, nutrient exhaustion occurring during the productive period suggests that chemical factors then control the phytoplankton development. One way of determining the potential limiting factor in
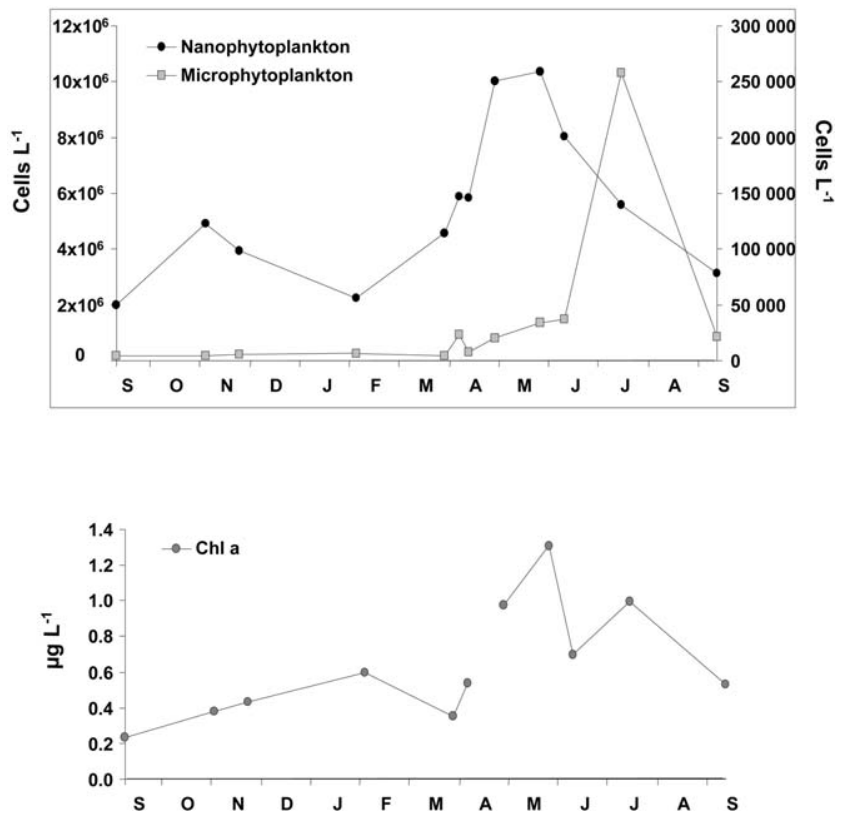

Fig. 9. (a) Seasonal evolution of microphytoplankton $-\square-$ (right axis) and of nanophytoplankton - $\bullet$ - (left axis) in cells $1^{-1}$. (b) Chl $a$ concentrations - $\mathrm{O}$ - at the $\mathrm{Chl} a$ maximum in $\mu \mathrm{g} \mathrm{l}^{-1}$.

the sense of Liebig's "law of minimum" (Liebig, 1840) is to examine the nutrient ratios in the water column. This ratio is derived from the composition of biogenic matter for living diatoms (Si:N:P = 16:16:1) (Brzezinski, 1985; Redfield et al., 1963) which gives an estimate of the nutrient requirement. All data collected at the SOFI site are plotted in Fig. 12 where the Si:N = 1, Si:P = 16 and $\mathrm{N}: \mathrm{P}=16$ lines delimit six areas, each characterizing a different hierarchy for the potential limiting factors. The same data are plotted on an annual cycle and versus depth in Fig. 13. From Fig. 12. P appears to be the primary potential limiting factor, followed equally by $\mathrm{Si}$ and N. The N:P ratio varied from 0.12 in September 1999 to 70 in October 1999. The Si:N ratio exhibited strong variations as well: values ranged between 0.04 in late-April and 130 in September 1999. Very low Si:N ratios were observed in late-April when $\mathrm{Si}(\mathrm{OH})_{4}$ concentrations were close to depletion. Del Amo et al. (1997) reported Si:N ratios of 0.2 in the Bay of Brest, which were already among the lowest ever published. Such low Si values are rarely documented anywhere in the ocean, and particularly for the Mediterranean Sea. Jacques and Tréguer (1986) reported for instance that $\mathrm{NO}_{3}+\mathrm{NO}_{2} / \mathrm{Si}$ ratios were usually close to 1 for the surface layers, and excluded thereby $\mathrm{Si}$ as a limiting factor. Nonetheless, it seems that spring Si depletion is a recurrent feature in coastal North Western Mediterranean waters. The Dyfamed database (http://www.obs-vlfr/jgofs2/sodyf/ home.htm) provides further elements: the Si concentration falls regularly under $1 \mu \mathrm{M}$ in fall and winter, but most often in July and September (this was the case for 8 years out of a 10 -year study). Values $<0.2 \mu \mathrm{M}$ were also measured in June, July, September, November and December for different years, confirming that the pattern observed at the SOFI site is not unusual. 

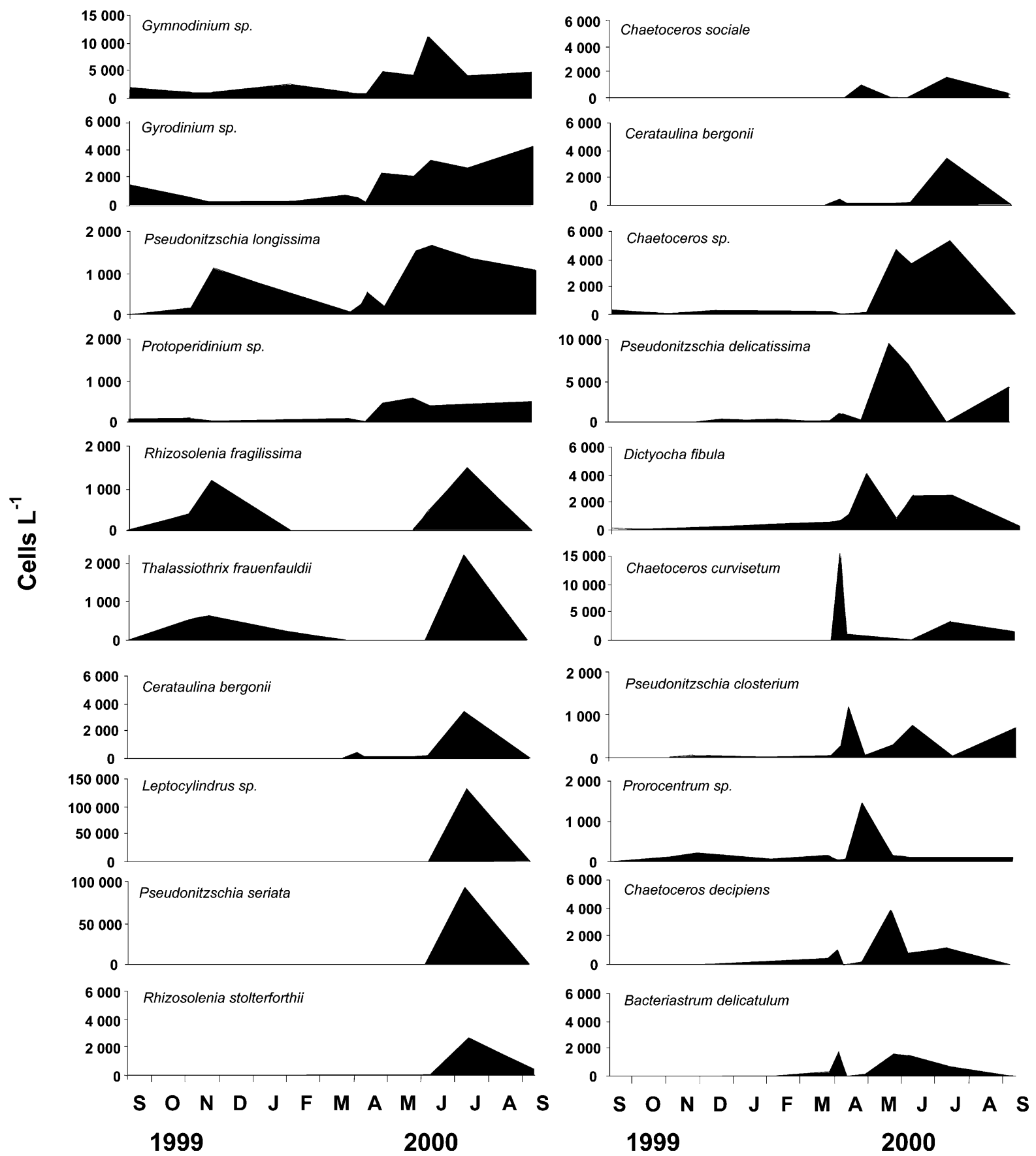

Fig. 10. Seasonal evolution of the dominant species cellular abundance, in cells $1^{-1}$.

The potential limiting factors exhibit different patterns according to the season and they also vary with depth Fig. 13. During fall 1999, N and P appeared as the principal potential limiting factors. In winter and early-spring, $\mathrm{P}$ became the primary potential limiting factor as previously observed by Diaz et al. (2001); water mixing increased DIN and $\mathrm{Si}(\mathrm{OH})_{4}$ concentrations while $\mathrm{PO}_{4}$ concentrations remained low $(<0.1 \mu \mathrm{M})$. During the onset of the spring bloom, in late-April, $\mathrm{Si}$ seemed to control phytoplankton development in the entire water column. Si also appeared limiting at the surface in May, which corresponded to the highest BSi accumulation. For the rest of the year (summer and fall), the water column could be divided in to two periods: $\mathrm{N}$ was the potential limiting factor in the surface layer $(0-50 \mathrm{~m})$, while $\mathrm{P}$ became the potential limiting factor in the waters below.

The extremely low Si:N and Si:P ratios in late-April can be explained by the 'silicate pump' model (Dugdale and Minas, 1995). Fig. 4 shows that nutrient remineralization in deep waters occurred earlier for DIN and $\mathrm{PO}_{4}$ than for $\mathrm{Si}(\mathrm{OH})_{4}$. Indeed, the increase in $\mathrm{DIN}$ and $\mathrm{PO}_{4}$ in the bottom layer started almost simultaneously with the onset of the bloom in late-April/May, while Si really increased by June. $\mathrm{Si}$ is lost from the surface layer more rapidly through sinking of diatoms or through fecal pellets while a larger fraction of 


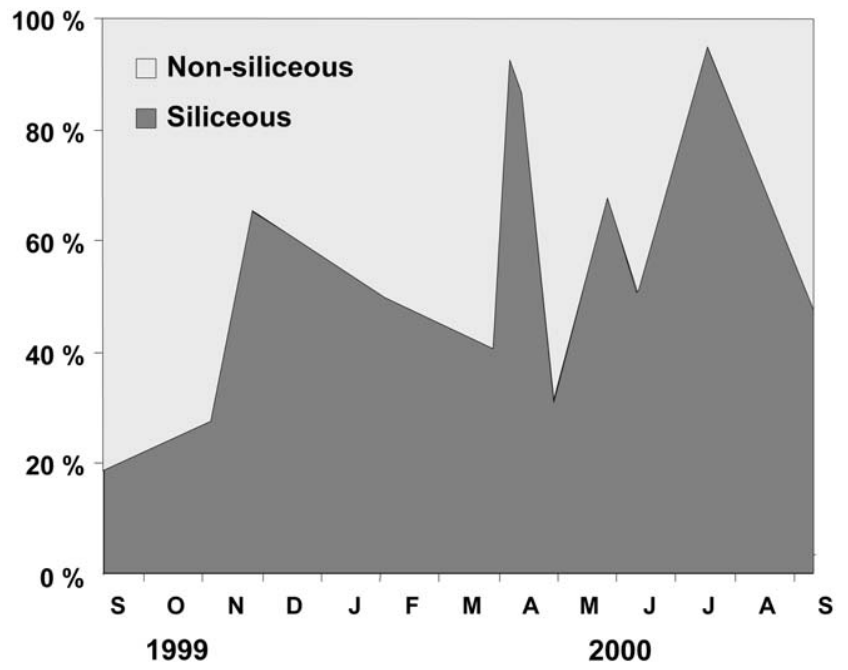

Fig. 11. Seasonal evolution of the relative abundance of siliceous phytoplankton (diatoms + silicoflagellates) vs. non-siliceous phytoplankton (dinoflagellates + cryptophyceans + prymnesiophyceans + coccolithophorids) at the $\mathrm{Chl} a$ maximum at SOFI.
$\mathrm{N}$ and $\mathrm{P}$ is recycled through the microbial loop. Particulate $\mathrm{Si}$ also takes longer time to dissolve, due to the organic coating protecting the frustules and due to Si dissolution kinetics (Dugdale and Minas, 1995).

Considering the fact that the SOFI site is under the influence of river discharge from time to time, it is interesting to examine the Si:N ratios for the Rhone river. Recent studies have shown that CWs under the influence of river discharge were exhibiting increasing dystrophy. Indeed the Si:N ratio of riverine waters has decreased drastically in a number of regions. In 'pristine conditions' the Si:N ratio may be as high as 17.4 (Meybeck, 1982), but in many regions this ratio now falls under 1 . This is the case, among others, in the Gulf of Mexico, in the Northern Adriatic (Justic et al., 1995), in the English channel (Wafar, 1981) and in the Bay of Brest where the ratio can be as low as 0.2 (Del Amo et al., 1997). Nutrient measurements realized monthly during our year survey in the Rhone river are shown on Fig. 14. During most of the year, $\mathrm{Si}$ : $\mathrm{N}$ ratios are below the usual value of $\mathrm{Si}: \mathrm{N}=1$, and vary from 0.46 in April to 1.18 in October, confirming the general

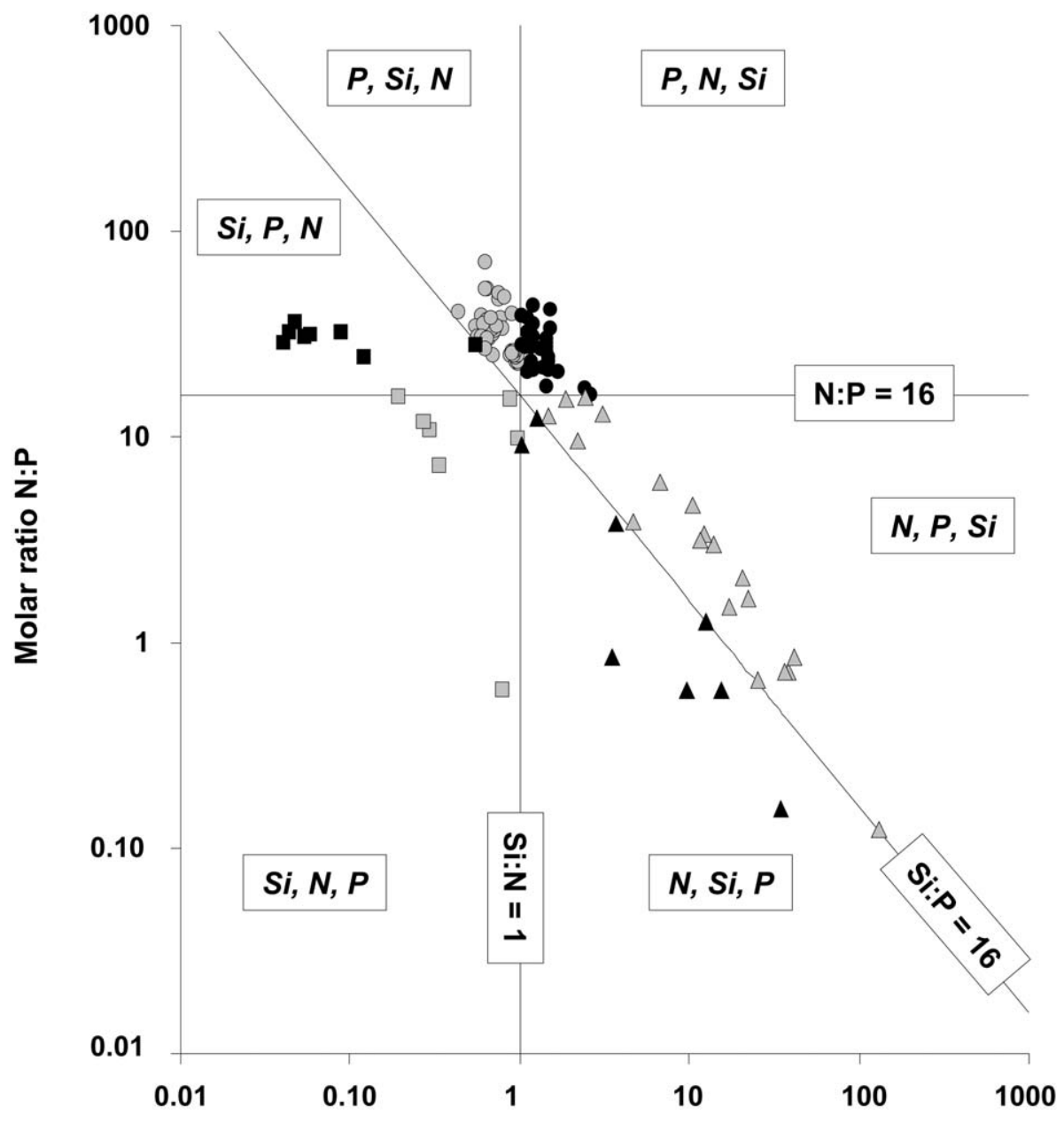

\section{Molar ratio Si:N}

Fig. 12. Si:N:P molar ratio of all data collected at SOFI from September 1999 to September 2000. In each area, delimited by the Brzezinski (1985) ratio and by the Redfield et al. (1963) ratio (Si:N:P = 16:16:1), the potential limiting nutrient (PLN) are reported in order of priority. Circles: P first PLN $(\bullet N$ second PLN, $\triangle$ Si second PLN). Triangles: N first PLN ( $\Delta$ Si second PLN, $\square$ P second PLN). Squares: Si first PLN ( $\square$ P second PLN, o N second PLN). 


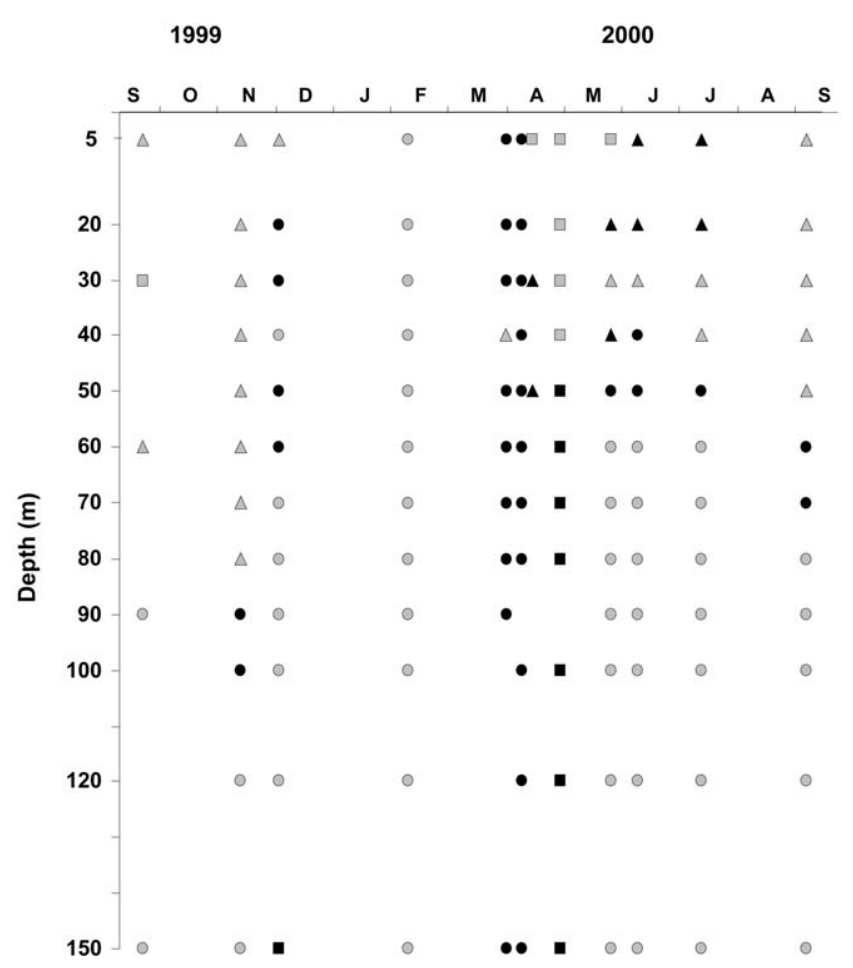

Fig. 13. Synthetic graph of the potential limiting nutrient in order of priority (same legend as Fig. 14) for each mission and vs. depth.

trend observed in other coastal areas concerning the decrease in the $\mathrm{Si}: \mathrm{N}$ ratio. However, it appears that Rhone river waters are strongly $\mathrm{P}$ deficient, with $\mathrm{N}: \mathrm{P}$ ratios as high as 115 in March, which is a probable consequence of the efforts made to reduce urban phosphate discharges.

Another approach for assessing the potential limiting factor is to compare ambient nutrient concentrations to halfsaturation constants $\left(K_{\mathrm{S}}\right)$ for $\mathrm{Si}, \mathrm{N}$ and $\mathrm{P}$ uptake. Indeed, considering nutrient ratio alone does not provide definitive evidence concerning the potential limiting factor. Actual limitation depends on a variety of factors, such as species composition, kinetic constants, regeneration rates and more widely on environmental conditions (Del Amo et al., 1997). Half-saturation constants for $\mathrm{Si}$ uptake were determined at two occasions (July and September 2000). On the other hand $K_{\mathrm{S}}$ for $\mathrm{N}$ and $\mathrm{P}$ were not measured during our survey, but a large set of data exists in the literature. Mean values of $0.2 \mu \mathrm{M}$ for $\mathrm{PO}_{4}, 2 \mu \mathrm{M}$ for DIN and $2 \mu \mathrm{M}$ for $\mathrm{Si}(\mathrm{OH})_{4}$ were used by Del Amo et al. (1997). Estimated $K_{\mathrm{S}}$ values for $\mathrm{Si}$ uptake Fig. 8) were high $(4.97 \mu \mathrm{M}$ in July and $3.46 \mu \mathrm{M}$ in September) but in good agreement with the range of 0.4$5 \mu \mathrm{M}$ given by Nelson and Tréguer (1992). Egge and Aksnes (1992) demonstrated from enclosure experiments that diatom dominance occurred irrespectively of the season if $\mathrm{Si}$ concentration exceeded a threshold of approximately $2 \mu \mathrm{M}$ and that otherwise diatom dominance shifted to flagellate dominance; and if initial $\left[\mathrm{Si}(\mathrm{OH})_{4}\right]$ was $<1.5 \mu \mathrm{M}$, a diatom bloom would not occur (Egge, 1998). According to Nelson and Dortch (1996), the situation most likely to provoke $\mathrm{Si}$ limitation of diatoms is characterized by waters having $\mathrm{Si}: \mathrm{N}$

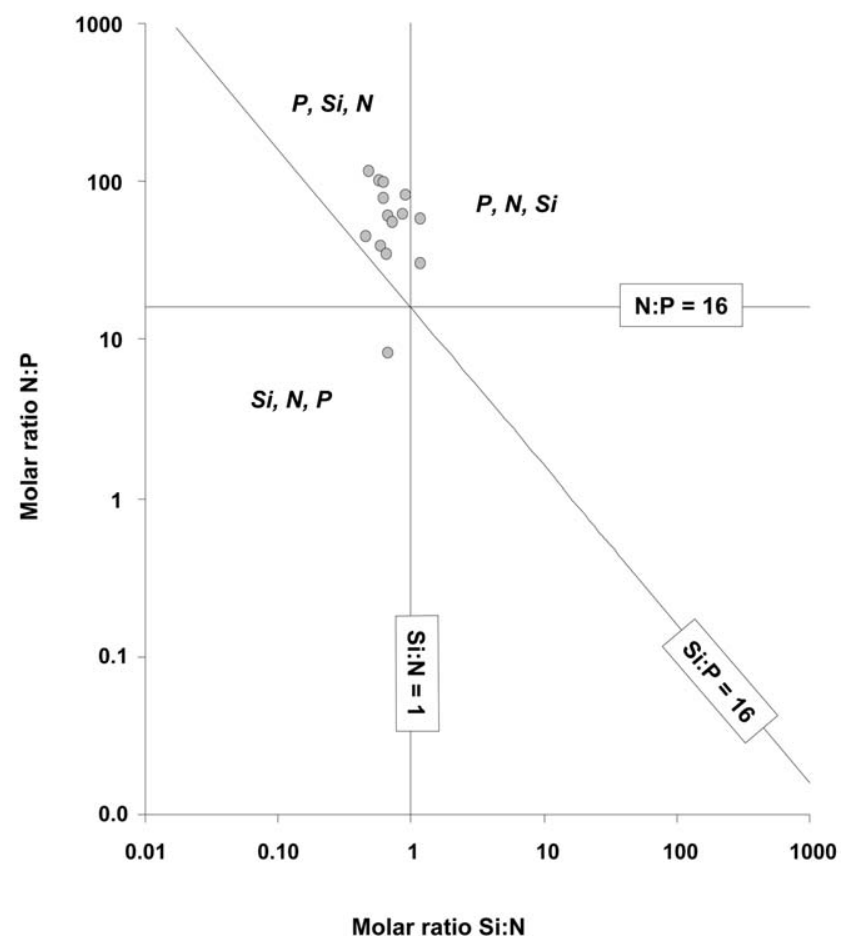

Fig. 14. Si:N:P molar ratio of monthly data collected in the Rhone river during the time-course of our survey. Symbols represent the potential limiting nutrient in order of priority (same legend as Fig. 14).

ratio $<1$ and $\left[\mathrm{Si}(\mathrm{OH})_{4}\right]<1.5 \mu \mathrm{M}$. As $K_{\mathrm{S}}$ for diatoms $>2 \mu \mathrm{M}$ are often reported, which is confirmed by our own measurements, $\left[\mathrm{Si}(\mathrm{OH})_{4}\right]$ values $<1 \mu \mathrm{M}$ and furthermore $<0.2 \mu \mathrm{M}$ may already be considered as limiting for diatom growth. During our study, there was no linear relationship between the relative abundance of siliceous phytoplankton and $\mathrm{Si}(\mathrm{OH})_{4}$ concentrations, but whenever the $\left[\mathrm{Si}(\mathrm{OH})_{4}\right]$ fell below $1 \mu \mathrm{M}$, the relative contribution of diatoms and silicoflagellates dropped to less than 35\%, confirming Egge's findings (Egge, 1998). The one exception occurred in July where diatoms represented $96 \%$ of the phytoplankton while $\mathrm{Si}(\mathrm{OH})_{4}$ concentration was slightly under $1 \mu \mathrm{M}$. However, the diatoms observed in July were probably originating from the inner Gulf of Marseille, and were brought at the SOFI site along with the mixed waters from the Rhone river. With water column $\mathrm{Si}: \mathrm{N}$ ratios ranging from 0.04 to 0.4 and $\left[\mathrm{Si}(\mathrm{OH})_{4}\right]<0.12 \mu \mathrm{M}$ in late-April, Si thus appears to be the most probable limiting nutrient at the beginning of the spring bloom. Comparison of the two approaches leaves unchanged the conclusions reached in Fig. 13 (potential limiting factor vs. depth and time). $\mathrm{N}$ is the most probable limiting factor in the surface layer in late-spring and summer, while $\mathrm{P}$ is limiting in depth and over the whole water column in winter.

\subsection{Seasonal cycle}

Four different biological and hydrological phases were observed at the SOFI site during our year survey. Integrated values for nutrients, biomass and uptake parameters and mean values for each season are summarized in Table 3 


\subsubsection{Fall (September-early November)}

The system was stratified with a deep thermocline; $\mathrm{NO}_{3}$ and $\mathrm{PO}_{4}$ were severely depleted, with the lowest values for all seasons (157.7 and $5.9 \mathrm{mmol} \mathrm{m}^{-2}$ ). Identically, biomass parameters such as BSi or Chl $a$ were at their lowest level with a mean value of $3.1 \mathrm{mmol} \mathrm{m}^{-2}$ and $24.9 \mathrm{mg} \mathrm{m}^{-2}$, respectively. Microphytoplankton was essentially nonsiliceous and dominated by dinoflagellates. Si kinetic experiments showed a rather high $V_{\max }\left(0.97 \mathrm{~d}^{-1}\right)$ and a high doubling rate (1.0 doubl. $\left.\mathrm{d}^{-1}\right)$. However, $V_{\text {ambient }}$ was limited to only $32 \%$ of $V_{\max }$ and the half-saturation constant was as high as $3.46 \mu \mathrm{M}$. Si/P and $\mathrm{Si} / \mathrm{N}$ nutrient ratios were rather elevated, but the high $K_{\mathrm{S}}$ measured was likely to impose a secondary Si limitation on phytoplankton development. LSi was highest in that season $\left(61.8 \mathrm{mmol} \mathrm{m}^{-2}\right)$, due to the enrichment of the bottom waters by a nepheloid layer.

\subsubsection{Winter (late November-March)}

This period was marked by an important cooling of the surface layer, with minimum values of $12.8{ }^{\circ} \mathrm{C}$ in February. The water column was homogeneous and nutrients were replenished, reaching their highest surface values in February, where vertical mixing was highest. This nutrient increase allowed moderate Chl $a$ build-up $\left(51.9 \mathrm{mg} \mathrm{m}^{-2}\right)$, but light limitation was likely to occur due to strong vertical mixing. In February, the ratio Chl a/cell number increased Fig. 9a, b implying a higher $\mathrm{Chl} a$ cell content, which can be an indication of light limitation. The relative abundance of siliceous phytoplankton increased slightly Fig. 11, in parallel with a decrease in the integrated $\mathrm{Si} / \mathrm{N}$ and $\mathrm{Si} / \mathrm{P}$ ratios due to biological uptake and with an increase in the $\mathrm{BSi} / \mathrm{Chl} a$ ratio. Integrated LSi was elevated $\left(45.0 \mathrm{mmol} \mathrm{m}^{-2}\right)$ and probably reflected bottom sediment resuspension throughout the water column.

\subsubsection{Spring (April-May)}

Warming and stratification of the surface layer began between mid- and late-April. At the same period, nutrients started to be depleted due to phytoplankton uptake and build-up of biomass. $\Sigma$ BSi and $\Sigma \mathrm{Chl} a$ were highest with $21.5 \mathrm{mmol} \mathrm{m}^{-2}$ and $62.1 \mathrm{mg} \mathrm{m}^{-2}$, respectively. Si appeared to be limiting for diatom growth, with a mean $\mathrm{Si} / \mathrm{N}$ and $\mathrm{Si} / \mathrm{P}$ integrated ratio for this season of 0.64 and 13.77, respectively. Si limitation maintained Si uptake rates at a low level. Indeed $\rho \mathrm{Si}$ increase was very small as compared to winter values, and $\Sigma \mathrm{BSi} / \Sigma \mathrm{POC}$ or $\Sigma \rho \mathrm{Si} / \Sigma \rho \mathrm{C}$ ratios remained under the ratio of 0.09-0.13 given by Brzezinski for cultured diatoms (Brzezinski, 1985), confirming the weak representation of diatoms. Non-siliceous phytoplankton was dominant during the Si exhaustion period, but diatoms dominated the assemblage in early-April and in May. The highest integrated $\mathrm{C}$ primary production occurred in late-April $(42.4 \mathrm{mmol}$ $\mathrm{m}^{-2}$, when dinoflagellates dominated the phytoplankton assemblage. The strongest increase in BSi and Chl $a$ occurred in May, during the first spring bloom. $\Sigma \mathrm{BSi} / \Sigma \mathrm{POC}$ was highest at this period, with a ratio of 0.064 , supporting the increase in diatom numbers and relative abundance. Integrated LSi was very low in this season, with $16.7 \mathrm{mmol} \mathrm{m}^{-2}$,

Table 3

Integrated values for nutrient, $\mathrm{Chl} a, \mathrm{BSi}$ and $\mathrm{LSi}$, particulate organic carbon, $\mathrm{C}$ primary production rates $(\rho \mathrm{C}), \mathrm{Si}$ uptake rates, $\mathrm{BSi} / \mathrm{POC}$ ratios and $\rho \mathrm{Si} / \rho \mathrm{C}$ ratios are listed below. Nutrients and biomass parameters were integrated over the $0-150 \mathrm{~m}$ layer (units in $\mathrm{mmol} \mathrm{m}^{-2}$ and in mg m${ }^{-2}$ for $\Sigma$ Chl $a$ ) while uptake rates were integrated over the euphotic layer $\left(0-70 \mathrm{~m}\right.$ ) (units in $\mathrm{mmol} \mathrm{m}^{-2} \mathrm{~d}^{-1}$ ). Mean integrated values were calculated for each season (bold numbers) (see Garcia et al., in preparation, for $\mathrm{C}$ primary production method).

\begin{tabular}{|c|c|c|c|c|c|c|c|c|c|c|c|}
\hline & $\begin{array}{l}\Sigma \mathrm{NO}_{3} \\
\left(\mathrm{mmol} \mathrm{m}^{-2}\right)\end{array}$ & $\begin{array}{l}\Sigma \mathrm{PO}_{4} \\
\left(\mathrm{mmol} \mathrm{m}^{-2}\right)\end{array}$ & $\begin{array}{l}\Sigma \mathrm{Si}(\mathrm{OH})_{4} \\
\left(\mathrm{mmol} \mathrm{m}^{-2}\right)\end{array}$ & $\begin{array}{l}\Sigma \mathrm{Chl} a \\
\left(\mathrm{mg} \mathrm{m}^{-2}\right)\end{array}$ & $\begin{array}{l}\Sigma \mathrm{BSi} \\
\left(\mathrm{mmol} \mathrm{m}^{-2}\right)\end{array}$ & $\begin{array}{l}\Sigma \mathrm{LSi} \\
\left(\mathrm{mmol} \mathrm{m}^{-2}\right)\end{array}$ & $\begin{array}{l}\Sigma \mathrm{POC} \\
\left(\mathrm{mmol} \mathrm{m}^{-2}\right)\end{array}$ & $\begin{array}{l}\sum r \mathrm{C} \\
(\mathrm{mmol} \\
\left.\mathrm{m}^{-2} \mathrm{~d}^{-1}\right)\end{array}$ & $\begin{array}{l}\sum r \mathrm{Si} \\
(\mathrm{mmol} \\
\left.\mathrm{m}^{-2} \mathrm{~d}^{-1}\right)\end{array}$ & $\begin{array}{l}\Sigma \mathrm{BSi} / \\
\Sigma \mathrm{POC} \\
(\mathrm{mol}: \mathrm{mol})\end{array}$ & $\begin{array}{l}\sum \rho \mathrm{Si} / \Sigma \rho \mathrm{C} \\
(\mathrm{mol}: \mathrm{mol})\end{array}$ \\
\hline S-99 & 175.0 & 9.1 & 193.7 & 24.2 & 5.1 & 93.3 & & & & & \\
\hline $\mathrm{N}-99$ & 140.4 & 2.6 & 154.7 & 25.6 & 1.0 & 30.3 & & & & & \\
\hline Fall & 157.7 & 5.9 & 174.2 & 24.9 & 3.1 & 61.8 & & & & & \\
\hline N-99 & 434.3 & 14.8 & 315.4 & 27.3 & 2.2 & 46.8 & & & & & \\
\hline $\mathrm{F}-00$ & 384.6 & 15.5 & 362.0 & 71.1 & 12.2 & 71.1 & 760.6 & 15.7 & & 0.016 & \\
\hline M-00 & 167.3 & 6.7 & 247.2 & 57.2 & 12.8 & 17.0 & 870.1 & 21.6 & 0.45 & 0.015 & \\
\hline Winter & 328.7 & 12.3 & 308.2 & 51.9 & 9.1 & 45.0 & 815.3 & 18.7 & 0.45 & 0.015 & \\
\hline $\mathrm{A}-00$ & 218.1 & 8.0 & 253.6 & 67.0 & 18.1 & 5.4 & & 19.9 & 0.51 & & 0.026 \\
\hline A- -00 & 213.2 & 16.8 & 124.4 & & & & & & & & \\
\hline $\mathrm{A}-00$ & 199.8 & 7.3 & 13.1 & 58.3 & 11.1 & 23.9 & 517.6 & 42.4 & 0.36 & 0.022 & 0.008 \\
\hline M-00 & 230.0 & 8.2 & 162.4 & 61.0 & 35.1 & 20.7 & 547.0 & 9.1 & 0.53 & 0.064 & 0.058 \\
\hline Spring & 215.3 & 10.0 & 138.4 & 62.1 & 21.5 & 16.7 & 532.3 & 23.8 & 0.47 & 0.043 & 0.031 \\
\hline $\mathrm{J}-00$ & 250.7 & 9.1 & 195.9 & 50.8 & 17.2 & 16.6 & 781.5 & 10.0 & 0.21 & 0.022 & 0.021 \\
\hline $\mathrm{J}-00$ & 349.7 & 12.6 & 241.9 & 80.6 & 36.9 & 20.0 & 815.8 & 10.9 & 1.40 & 0.045 & 0.129 \\
\hline S-00 & 254.7 & 9.5 & 230.9 & 36.0 & 3.7 & 10.9 & 255.9 & 3.8 & 0.14 & 0.015 & 0.038 \\
\hline Summer & 285.0 & 10.4 & 222.9 & 55.8 & 19.3 & 15.8 & 617.7 & 8.2 & 0.58 & 0.027 & 0.062 \\
\hline
\end{tabular}


which may be explained by the stabilization of the water column.

\subsubsection{Summer (June-August)}

During summer, integrated BSi and Chl $a$ remained high, due to the high biomass episode recorded in July. In June, a southern wind event just prior to the sampling date provoked water mixing Fig. 3 and an increase in the nutrient stock. The increase in $\mathrm{Si}(\mathrm{OH})_{4}$ concentration between May and June was higher than the $\left[\mathrm{NO}_{3}\right]$ and $\left[\mathrm{PO}_{4}\right]$ increase, inducing a shift in the limiting factor, from $\mathrm{Si}$ to $\mathrm{N}$ in the surface layer and from $\mathrm{Si}$ to $\mathrm{P}$ in the aphotic layer Fig. 13. In July, microphytoplankton cell numbers rose up to $258000{\text { cells } 1^{-1}}^{-1}$ at the $\mathrm{Chl} a$ maximum, following a period of $12 \mathrm{~d}$ of strong northwesterly winds implying lateral advection of water masses from the inner GL. Species composition was also markedly different in July, supporting the hypothesis of allochtonous origin of phytoplankton cells. This sharp increase was not followed by any similar rise in Chl $a$ or carbon primary production, which increased only slightly by comparison to May values where cell number was only 34000 cells $1^{-1}$. The number of diatoms increased more than 10 times between May and July, but $\Sigma \rho \mathrm{Si}$ increased only by a factor 2.6 and $\Sigma$ BSi remained fairly similar. This suggests that this massive phytoplankton increase, almost entirely constituted of two species of diatoms, was in a poor physiological state or senescent and that diatoms were likely to be less silicified. The integrated $\mathrm{BSi} / \mathrm{POC}$ ratio indeed decreased from 0.064 in May to 0.045 in July. Kinetic experiments clearly showed a high degree of $\mathrm{Si}$ limitation. $V_{\max }$ was low $\left(0.19 \mathrm{~d}^{-1}\right)$ and ambient specific uptake rate represented only $27 \%$ of the potential maximum uptake rate. Doubling rate was lowered $\left(k=0.05\right.$ doubl. $\left.\mathrm{d}^{-1}\right)$ while the $K_{\mathrm{S}}$ value of $4.97 \mu \mathrm{M}$ was much higher than the ambient $\mathrm{Si}(\mathrm{OH})_{4}$ concentration $(0.95 \mu \mathrm{M})$. Integrated LSi was lowest in summer $\left(15.8 \mathrm{mmol} \mathrm{m}^{-2}\right)$, probably due to stratification and subsequent stabilization of the water column. However, surface concentrations increased under the influence of inputs of Rhone river water in July. In late-summer (July-August), surface nutrient concentrations remained low while increasing in bottom waters (90-150 m) as a probable consequence of remineralization of sinking organic matter.

Despite the clear seasonal trends depicted above, a paradox seems to emerge from the data concerning the Si cycle: the data showed a near complete exhaustion of $\mathrm{Si}(\mathrm{OH})_{4}$ over the whole water column while this biological consummation of Si was not matched by any equivalent increase in BSi or in Si uptake rates which remained extremely low. Different explanations can be used to explain this apparent discrepancy between the $\Delta \mathrm{Si}(\mathrm{OH})_{4}$ and the $\Delta \mathrm{BSi}$. Whenever comparing stocks and fluxes together, one is confronted with the problem that stocks, such as $\mathrm{Si}(\mathrm{OH})_{4}$ or BSi concentrations, reflect an integrated image, while fluxes such as Si uptake rates or grazing rates reflect the situation met on the day measurements are made. Due to the time elapsed between each sampling as compared to the short-scale variability
Table 4

Comparative table of integrated annual $\mathrm{Si}$ production rates (in mol $\mathrm{Si} \mathrm{m}^{-2}$ per year) for different open-ocean and coastal areas

\begin{tabular}{lcl}
\hline Location & $\begin{array}{l}\text { Integrated annual } \\
\text { production } \\
\text { (mol Si m }{ }^{-2} \text { per year) }\end{array}$ & References \\
\hline SOFI & 0.14 & This study \\
Mid-ocean gyres & 0.20 & $\begin{array}{l}\text { Brzezinski and Nelson, } \\
\text { BATS (Sargasso Sea) }\end{array}$ \\
Santa Barbara basin & 0.24 & $\begin{array}{l}\text { Nelson and Brzezinski, } \\
\text { Coastal upwellings }\end{array}$ \\
\hline
\end{tabular}

encountered at the SOFI site (frequent strong wind events, Rhone incursions, CNM variability), episodes of higher $\mathrm{Si}$ uptake rates have probably been missed in our sampling. Secondly, intensive grazing of diatoms may have precluded any measurements of high biomass and even though no data are available, zooplanktonic clearance rates could have been significant if we are to explain the low siliceous biomass encountered. Finally, other loss terms to be considered are events of rapid sedimentation of diatoms after a bloom that could have been missed during sampling as well as lateral advection of biomass.

\subsection{Diatom contribution to primary production and comparison with other regions}

An estimate of the annual integrated $\mathrm{Si}$ production was derived from the production profiles obtained between March and September 2000. The extremely low Si production rates observed in September 2000 were representative of the non-productive period and were extrapolated to the period ranging from September 1999 to March 2000. The integrated annual Si production amounted to $0.14 \mathrm{~mol} \mathrm{Si} \mathrm{m}^{-2}$ per year. Using the $0.09-0.13$ range for diatom $\mathrm{Si}$ :C mol ratio (Brzezinski, 1985), the annual Si production yielded a range of 1.1-1.6 mol C m $\mathrm{m}^{-2}$ per year. This annual production rate may yet be considered as a low estimate, taking into consideration that Rhone incursion events, which significantly raise the $\mathrm{Si}$ production budget, may have occurred between the campaigns. The integrated annual carbon primary production for the same period was $4.5 \mathrm{~mol} \mathrm{C} \mathrm{m}^{-2}$ per year (Garcia et al., in preparation) which is very close to the value of $4.1 \mathrm{C} \mathrm{m}^{-2}$ per year previously calculated by Diaz (2000) during the 1998-1999 survey. Diatoms consequently accounted for 24$36 \%$ of the total annual primary production. This is very close to the value of $25 \%$ estimated for the Central North Pacific in mid-summer (Brzezinski et al., 1998) or to the estimate of 34\% given for the Equatorial Pacific (Blain et al., 1997). Si integrated annual production is similar to that observed in mid-ocean gyres and in other oligotrophic areas (Sargasso Sea), but is one order of magnitude lower than the values found in coastal sites such as the Santa Barbara basin or in coastal upwellings Table 4. Silica production at SOFI appears to be one of the lowest ever reported for the world 
ocean up to date, which is surprising for a coastal site. On the other hand, SOFI remains most of the year under the direct influence of the NMC, implying a high degree of oligotrophy and successive nutrient limitation during the productive period.

\section{Conclusions}

A clear seasonal cycle of BSi and LSi standing stocks was evidenced at SOFI. Integrated BSi was highest in spring and summer during the major phytoplankton developments (21.5 and $19.3 \mathrm{mmol} \mathrm{m}^{-2}$ ). In winter relatively high $\mathrm{Chl} a$ concentrations originating from non-siliceous phytoplankton were sustained over the water column. Due to frequent wind events the water column was well-mixed during winter, allowing sediment resuspension and resulting in high LSi integrated stocks $\left(61.8\right.$ and $\left.45.0 \mathrm{mmol} \mathrm{m}^{-2}\right)$. The data collected showed that correction for the interference between BSi and LSi was needed in CWs. The use of the aluminum correction method for BSi measurements (Kamatani and Oku, 2000) may be the subject of further investigations for water column and sediment trap samples. Siliceous phytoplankton (diatoms and silicoflagellates) represented an average contribution of 57\% of microphytoplankton abundance at the $\mathrm{Chl} a$ maximum throughout the year, implying that dissolved $\mathrm{Si}$ availability may play an important role in driving new production. This paper reports $\mathrm{Si}$ depletion over the entire water column during the onset of the spring bloom, which has never been documented to our knowledge for the Mediterranean Sea. The "silicate pump" model thus seems to apply at the SOFI site (Dugdale and Minas, 1995) with Si lost more rapidly from the surface layer than $\mathrm{N}$ or $\mathrm{P}$, which could be more rapidly recycled via the food web. This study also reports the first in situ Si uptake rates measurements for the Mediterranean Sea. Integrated Si uptake rates $(\Sigma \rho \mathrm{Si}=0.14$ $1.40 \mathrm{mmol} \mathrm{Si} \mathrm{m}^{-2} \mathrm{~d}^{-1}$ ) were close to the minimum value of $0.1 \mathrm{mmol} \mathrm{Si} \mathrm{m}^{-2} \mathrm{~d}^{-1}$ reported for the World Ocean (Nelson et al., 1995) indicating a high degree of Si limitation. Halfsaturation constants $\left(K_{\mathrm{S}}\right)$, derived from kinetic experiments, were much superior $(3.46$ and $4.97 \mu \mathrm{M})$ to ambient $\mathrm{Si}(\mathrm{OH})_{4}$ concentrations, which tends to confirm this hypothesis. From nutrients molar ratios, it appeared that successive nutrient limitation may occur at SOFI: P seemed to be potentially limiting early in the season, followed by $\mathrm{Si}$ during the onset of the bloom, while $\mathrm{N}$ appeared to be limiting in summer and fall. The integrated $\mathrm{Si}$ annual production was estimated to $0.14 \mathrm{~mol} \mathrm{Si} \mathrm{m}{ }^{-2}$ per year, a value comparable to open-ocean oligotrophic systems, such as mid-ocean gyres, but an order of magnitude lower than values found for other coastal sites. Yet, this annual budget may be considered as a low estimate if other Rhone incursion events occurred, however, undocumented at the SOFI site due to sampling strategy. The contribution of diatoms to $\mathrm{C}$ primary production amounted to $24-36 \%$, which is also characteristic for oligotrophic systems. The SOFI site is placed most of the year under the influence of the oligotrophic NMC and, is therefore, not representative of the coastal shelf area. A previous study also showed the poor representativity of the SOFI site on a regional scale (Diaz, 2000). Thus, the calculated Si annual budget may not be extrapolated to the inner GL, which is probably more impacted by the river discharges with $\mathrm{Si}: \mathrm{N}<$ 1. Further studies on a larger spatial scale are thus needed to assess the potential role of $\mathrm{Si}$ in driving new production and in structuring phytoplankton communities on continental margins.

\section{Acknowledgements}

This study was supported by the PNOC. We would also like to thank the crews of the R/V Téthys and G. Petit for making these missions possible. F. Diaz is acknowledged for his comments and constructive remarks on this manuscript. A special thanks to the many students who volunteered to come on board and for their help at sea. D. Conley and an anonymous reviewer are thanked for their helpful comments on the manuscript.

\section{References}

Berger, W.H., Smetacek, V.S., Wefer, G., 1989. Ocean productivity and paleoproductivity, an overview. In: Berger, W.H., Smetacek, V.S., Wefer, G. (Eds.), Productivity of the Ocean: Present and Past. Wiley, pp. 1-34.

Béthoux, J.P., Morin, P., Chaumery, C., Connan, O., Gentili, B., RuizPino, D., 1998. Nutrients in the Mediterranean Sea, mass balance and statistical analysis of concentrations with respect to environmental change. Mar. Chem. 63 (1-2), 155-169.

Blain, S., Leynaert, A., Tréguer, P., Chrétiennot-Dinet, M.-J., Rodier, M., 1997. Biomass, growth rates and limitation of Equatorial Pacific diatoms. Deep-Sea Res. 44, 1255-1275.

Brzezinski, M.A., Nelson, D.M., 1986. A solvent extraction method for the colorimetric determination of nanomolar concentrations of silicic acid in seawater. Mar. Chem. 19, 139-151.

Brzezinski, M.A., Phillips, D.R., Chavez, F.P., Friederich, G.E., Dugdale, R.C., 1998. Silica production in the Monterey, California, upwelling system. Limnol. Oceanogr 42 (8), 1694-1705.

Brzezinski, M.A., 1985. The Si:C:N ratio of marine diatoms: interspecific variability and the effect of some environmental variables. J. Phycol. 21, 347-357.

Conan, P., 1996. Variabilité et bilan de la production primaire en zone côtière (Méditerranée Nord occidentale; entrée du golfe du Lion) en relation avec les systèmes biologiques, chimiques et hydrodynamiques (Courant Nord Méditerranéen). Ph.D. thesis, Université d'Aix-Marseille II, vol. I $185 \mathrm{p}$.

Conan, P., Millot, C., 1995. Variability of the Northern Current off Marseilles, western Mediterranean Sea, from February to June 1992. Oceanol. Acta 18 (2), 193-205.

Copin-Montégut, C., 1988. Eléments majeurs des particules en suspension de la Méditerranée occidentale. Oceanol. Acta No. sp., 95-102.

Coste, B., Minas, H.J., 1977. Conditions estivales dans la divergence de Méditerranée nord-occidentale. IV. Hydrologie et sels nutritifs. Ann. Inst. océanogr. Paris 53 (2), 177-188.

Del Amo, Y., Le Pape, O., Tréguer, P., Quéguiner, B., Ménesguen, A., Aminot, A., 1997. Impacts of high-nitrate freshwater inputs on macrotidal ecosystems. I. Seasonal evolution of nutrient limitation for the diatom-dominated phytoplankton of the Bay of Brest (France). Mar. Ecol. Progr. Ser. 161, 213-224. 
Denis, L., 1999. Dynamique des flux d'oxygène et de sels nutritifs à l'interface eau-sédiment sur la marge continentale du golfe du Lion (Méditerranée nord occidentale). Ph.D. thesis, Université d'AixMarseille II 129 p.

Diaz, F., 2000. Evolution saisonnière de la production primaire et des processus d'assimilation — régénération de l'azote dans le golfe du Lion. Estimation d'un bilan de carbone. Approches in situ et modélisation. Ph.D. thesis, Université de la Méditerranée 339 p.

Diaz, F., Raimbault, P., Boudjellal, B., Garcia, N., Moutin, T., 2001. Early spring phosphorus limitation of primary productivity in a NW Mediterranean coastal zone (Gulf of Lions). Mar. Ecol. Progr. Ser. 211, 51-62.

Dugdale, R.C.W.F.P., Minas, H.J., 1995. The role of a silicate pump in driving new production. Deep-Sea Res. 42, 697-719.

Egge, J.K., Aksnes, D.L., 1992. Silicate as regulating nutrient in phytoplankton competition. Mar. Ecol. Progr. Ser. 83, 281-289.

Egge, J.K., Jacobsen, A., 1997. Influence of silicate on particulate carbon production in phytoplankton. Mar. Ecol. Progr. Ser. 147, 219-230.

Egge, J.K., 1998. Are diatoms poor competitors at low phosphate concentrations? J. Mar. Syst. 16, 191-198.

Garcia et al., in preparation.

Jacques, G., Tréguer, P., 1986. In: Tréguer, P., Jacques, G. (Eds.), Les écosystèmes pélagiques marins III. L'océan Antarctique. La Méditerranée occidentale. Masson,, Paris, pp. 255.

Jickells, T.D., 1998. Nutrient biogeochemistry of the coastal zone. Science 281, 217-222.

Kamatani, A., Oku, O., 2000. Measuring biogenic silica in marine sediments. Mar. Chem. 68, 219-229.

Koroleff, F., 1969. Direct determination of ammonia in natural waters as indophenol blue. Int. Counc. Explor. Sea C.M. 9 (C), 19-22.

Lacombe, Tchernia, 1972. Caractères hydrologiques et circulation des eaux en Méditerranée. In: Stanley, D.J. (Ed.), The Mediterranean Sea. Dowden, Hutchinson and Ross,, Stroudsberg, pp. 25-36.

Leynaert, A., 1993. La production de silice biogénique dans l'océan : de la mer de Weddell à l'océan Antarctique. Ph.D. thesis, Université Pierre et Marie Curie, (Paris VI), pp. 99.

Le Pape, O., Del Amo, Y., Menesguen, A., Aminot, A., Quéguiner, B., Tréguer, P., 1996. Resistance of a coastal ecosystem to increasing eutrophic conditions: the Bay of Brest (France), a semi-enclosed zone of Western Europe. Cont. Shelf Res. 16 (5), 1885-1907.

Liebig, J., 1840. Die Chemie in ihrer anvendung auf agricultur, und physiologie. fourth ed. Taylor and Watson,, London 1847.

Liu, K.K., Atkinson, L., Chen, C.T.A., Gao, S., Hall, J., Macdonald, R.W., Talaue, McManus, L., Quiñones, R., 2000. Exploring continental margin carbon fluxes on a global scale. EOS, Trans. A.G.U. 81 (52), 641-644.

Meybeck, M., 1982. Carbon, nitrogen, and phosphorus transport by world rivers. Am. J. Sci. 282, 401-450.

Justic, D., Rabalais, N.N., Turner, R.E., 1995. Stoichiometric nutrient balance and origin of coastal eutrophication. Mar. Pollut. Bull. 30, 41-46.

Millot, C., 1999. Circulation in the Western Mediterranean Sea. J. Mar. Syst. 20, 423-442.

Miserocchi, S., Faganeli, J., Balboni, V., Heussner, S., Monaco, A., Kerhervé, P., 1999. Characteristics and sources of the settling particulate organic matter in the South Adriatic basin. Org. Geochem. 30 (6), 411-421.

Monaco, A., Biscaye, P., Soyer, J., Pocklington, R., Heussner, S., 1990. Particle fluxes and ecosystem response on a continental margin: the 1985-1988 Mediterranean ECOMARGE experiment. Cont. Shelf Res. 10 (9-11), 809-839.

Nelson, D.M., Dortch, Q., 1996. Silicic acid depletion and silicon limitation in the plume of the Mississippi River: evidence from kinetic studies in spring and summer. Mar. Ecol. Progr. Ser. 136, 163-178.
Nelson, D.M., Goering, J.J., 1978. Assimilation of silicic acid by phytoplankton in the Baja California and northwest Africa upwelling systems. Limnol. Oceanogr. 23 (3), 508-517.

Nelson, D.M., Tréguer, P., 1992. Role of silicon as a limiting nutrient to Antarctic diatoms: evidence from kinetic studies in the Ross Sea iceedge zone. Mar. Ecol. Progr. Ser. 80, 255-264.

Nelson, D.M., Smith Jr., W.O., Muench, R.D., Gordon, L.I., Sullivan, C.W., Husby, D.M., 1989. Particulate matter and nutrient distribution in the ice edge zone of the Weddell Sea: relationship to hydrography during late summer. Deep-Sea Res. 36, 191-209.

Nelson, D.M., Tréguer, P., Brzezinski, M.A., Leynaert, A., Quéguiner, B., 1995. Production and dissolution of biogenic silica in the ocean: revised global estimates, comparison with regional data and relationship to biogenic sedimentation. Global Biogeochem. Cycles 9, 359-732.

Officer, C.B., Ryther, J.H., 1980. The possible importance of silicon in marine eutrophication. Mar. Ecol. Progr. Ser. 3, 83-91.

Price, N.B., Brand, T., Pates, J.M., Mowbray, S., Theocharis, A., Civitarese, G., Miserocchi, S., Heussner, S., Lindsay, F., 1999. Horizontal distributions of biogenic and lithogenic elements of suspended particulate matter in the Mediterranean Sea. Progr. Oceanogr. 44, 191-218.

Ragueneau, O., Tréguer, P., 1994. Determination of biogenic silica in coastal waters: applicability and limits of the alkaline digestion method. Mar. Chem. 45, 43-51.

Raimbault, P., Rodier, M., Taupier-Letage, I., 1988. Size fraction of phytoplankton in the Ligurian Sea and the Algerian Basin (Mediterranean Sea): size fraction versus total concentrations. Mar. Microb. Food Webs $3,1-7$.

Raimbault, P., Pouvesle, W., Boudjellal, B., 1999. A semi-automatic, wetoxidation method for simultaneous determination of particulate carbon, nitrogen and phosphorus collected on filters. Mar. Ecol. Progr. Ser. 180, 289-295.

Redfield, A.C., Ketchum, B.H., Richards, F.A., 1963. The influence of organisms on the composition of sea water. In: Hill, M.N. (Ed.), The Sea. Wiley-Interscience, New York, pp. 26-77.

Schlitzer, R., 2002. Ocean Data View. http://www.awibremerhaven.de/GEO/ODV.

Shipe, R.F., Brzezinski, M.A., 2001. A time series study of silica production and flux in an eastern boundary region: Santa Barbara Basin, California. Global Biogeochem. Cycles 15 (2), 517-531.

Smayda, T.J., 1990. Novel and nuisance phytoplankton blooms in the sea: evidence for a global epidemic. In: Granéli, E. (Ed.), Toxic Marine Phytoplankton. Elsevier, pp. 29-40.

Sournia, A., 1978. Phytoplankton Manual. UNESCO (Eds.), Paris, pp. 337.

Strickland, J.D.H., Parsons, T.R., 1972. A practical handbook of seawater analysis. Fish. Res. Bd. Can. Bull. 167, 1-310.

Tréguer, P., Le Corre, P., 1975. Laboratoire d'Océanographie Chimique. U.B.O., Brest.

Tréguer, P., Lindner, L., Van Bennekom, A.J., Leynaert, A., Panouse, M., Jacques, G., 1991. Production of biogenic silica in the Weddell-Scotia Seas measured with ${ }^{32} \mathrm{Si}$. Limnol. Oceanogr. 36, 1217-1227.

Utermöhl, M., 1931. Über das umgekehrte mikroskop. Arch. Hydrobiol. Plankt. 22, 643-645.

Wafar, M., 1981. Nutrients, primary production, and dissolved and particulate organic matter in well-mixed temperate coastal waters (Bay of Morlaix, western English Channel). Université de Paris VI, pp. 226.

Wassmann, P., Egge, J.K., Reigstad, M., Aksnes, D., 1996. Influence of dissolved silicate on vertical flux of particulate biogenic matter. Mar. Poll. Bull. 33 (1-6), 10-21.

Wilkinson, G.N., 1961. Statistical estimations in enzyme kinetics. Biochem. J. 80, 324-332.

Wollast, R., 1991. The coastal organic carbon cycle: fluxes, sources and sinks. In: Mantoura, R.F.C., Marti, J.M., Wollast, R. (Eds.), Ocean Margin Processes in Global Change. Wiley J., Sons Ltd. 